\title{
13. CENOZOIC TERRIGENOUS SEDIMENTS IN THE WESTERN SOUTH ATLANTIC
}

\author{
E.M. Emelyanov and E.S. Trimonis, \\ P.P. Shirshov Institute of Oceanology, U.S.S.R. Academy of Sciences, Kaliningrad, U.S.S.R.
}

Terrigenous sediments (those with less than $30 \%$ $\mathrm{CaCO}_{3}$ and amorphous $\mathrm{SiO}_{2}$ ) presently occur over $28.9 \%$ of the whole Atlantic Ocean area. Taking into account ice-rafted deposits (1.3\%) and red clays (7.9\%), the area covered is $38.1 \%$ of the total, or almost 36 million square kilometers (Emelyanov et al., 1975). Terrigenous sediments are especially widespread in the western Atlantic, which receives the discharge of the principal arteries that drain about $87 \%$ of South America-such as the Amazon, Paraná, Orinoco, and São Francisco rivers. We have every reason to suppose that products of South American denudation played an important role in earlier Cenozoic sedimentation as well.

To explore this hypothesis in detail, we analyzed several hundred samples from all sites of Leg 39 (Figure 1), concentrating on minerals and elements which might indicate a South American source.

Grain-size analyses of uncemented sediments were performed on 72 samples, using the settling method (Petelin, 1961, 1967) and sediment balance (Prokoptsev, 1964); six size fractions were distinguished: $>0.1,0.1-0.5,0.05-0.01,0.01-0.005,0.005-0.001$, and $<0.001 \mathrm{~mm}$ (Table 1). The coarse aleurite fraction (0.1$0.05 \mathrm{~mm}$ ) was separated in bromoform into heavy (sp. gr. $>2.9$ ) and light subfractions (Tables 2 and 3), and the immersed particles studied under the polarizing microscope. In counting particles (300 to 400 per sample), we accounted for all minerals present in the subfractions (opaque, biogenic, and chemogenic); the minerals counted in each subfraction totalled $100 \%$.

We determined compositions of the sample sediments by wet chemical analysis, atomic absorption spectrometry, and quantitative spectral analysis, all of which are described by E.M.E. in a separate report in this volume. We also performed X-ray diffraction analysis on part of the samples ground for chemical study, using two methods. The first (Gorbunova, 1969) permits determination of the content, in weight percent, of quartz, plagioclases, and orthoclases in the bulk sediment sample (Table 4). The second method yields content of quartz, feldspars, clay minerals, carbonates, and others; this technique is similar to that of Rex and Murray (1970) for studying deepwater drilling cores. The bulk samples were analyzed, and mineral content determined from the sum of crystalline phases (Table $5)$.

\section{GUIANA BASIN AND VEMA FRACTURE ZONE}

At present, sediments from the Amazon are deposited chiefly in the Guiana Basin and the Vema Fracture Zone (Bader et al., 1970; Emelyanov and
Kharin, 1974), and those of the Orinoco come to rest primarily in the Caribbean Sea (Demerara Coastal Investigations Report, 1962). The Amazon Cone of gray, unconsolidated terrigenous pelitic and peliticaleuritic muds extends from the brow of the shelf off the Amazon estuary up to the North American Basin (Figure 1B).

The following minerals prevail in the Amazon sediment and pro-estuarial muds: quartz, feldspars, and chamositic aggregates in the light subfraction, and ilmenite-magnetite, limonite-hematite, epidote-zoisite, hornblende, clinopyroxenes, zircon, monacite, apatite, and others, in the heavy subfraction. A high illite/kaolinite ratio of 2.3 (Gibbs, 1967; Milliman et al., 1975) occurs in the Amazon effluence of the coastal Atlantic. In contrast, kaolinite occurs more often than illite in discharges of other, smaller rivers of northern Brazil. Chlorite constitutes less than $5 \%$ of these sediments.

Approximately the same complex of clastic minerals predominates in deepwater sediments of the Guiana Basin. The Amazon discharge influences the whole deepwater part of this basin, which may be defined as a separate Guianean terrigenous mineralogic province (Figure 2).

Data from Sites 26 (Bader et al., 1970) and 353 (Table 2) show that quartz, feldspars, and green and yellow mica prevail among light minerals in Quaternary sediments of the Vema Fracture Zone. As the X-ray diffraction data indicate (Table 4), quartz content of sediments from Site 353 is very high (up to $58 \%$ ), but feldspar content is less than $6 \%$. The high ratio of quartz to feldspar (>5-10) characterizes detritus from land in an equatorial humid zone, where feldspars are decomposed almost completely (Emelyanov et al., 1975).

The heavy-mineral suite of the Guiana Basin is typical of an Amazon source; it contains common ilmenite-magnetite, hornblende, epidote-zoisite, biotite, and pyroxenes. Heavy-mineral content of the fraction $0.1-0.05 \mathrm{~mm}$ in samples from Hole 353 ranges from 2.2 to $14.2 \%$ (Table 3 ). The Pleistocene section (thickness $264 \mathrm{~m}$ ) is largely derived from the Amazon. Accumulation rate of these sediments was extraordinarily high -90 to $120 \mathrm{~cm} / 1000$ years (see Site 353 chapter); a considerable part of the Pleistocene section was deposited by turbidity currents.

The Amazon discharge played a lesser role in Cenozoic sedimentation in the central (Sites 354 and 142) and southeastern (northwest of Sites 23-25) parts of the Guiana Basin. Biogenic material sharply diluted the terrigenous contribution, and marly nannofossil 


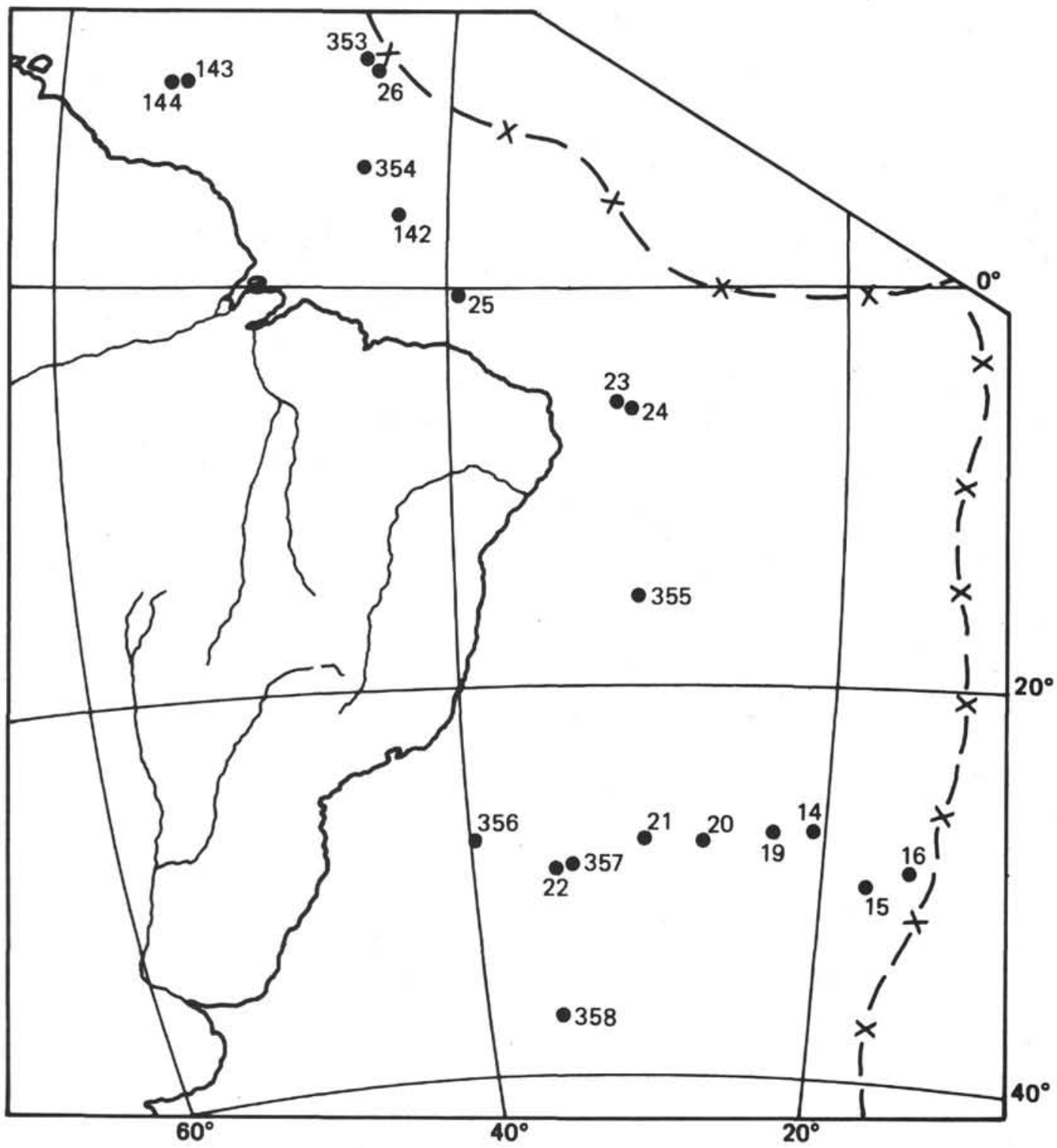

Figure 1a. Bottom sediments in the western South Atlantic in different stages of the Cenozoic, based on the data of deep-sea drilling: disposition of sites.

and nannofossil-foraminifer muds and chalk and partially siliceous muds accumulated in these areas. Marly and highly calcareous deposits, containing $30 \%$ to $60 \%$ and $10 \%$ to $30 \%$ terrigenous material, respectively, prevail in the Paleocene-Neogene of the Ceará Rise. Significant deposition of terrigenous sediments began there in the Pleistocene, as the lower carbonate content and higher sedimentation rate $(10 \mathrm{~cm} / 1000$ years) indicate (Figure 3). The terrigenous deposition process is more apparent at the Ceará Abyssal Plain (Site 142). Here, turbidity currents laid down layers of sand, occasionally during the Miocene and frequently during the Pleistocene, when the sedimentation rate in this area reached $15 \mathrm{~cm} / 1000$ years.

Mineral compositions of suspended material and of Recent sediments (Emelyanov and Kharin, 1974) indicate that the Amazon sediments are penetrating the westernmost and southeastern parts of the Guiana Basin, and are governing terrigenous sedimentation there. This same process has operated since the Miocene, when the Amazon began emptying into the Atlantic (Oliveira, 1956). The prevalence in these deposits of such heavy minerals, typical of the Amazon discharge, as magnetite-ilmenite, hornblende, epidotezoisite, garnet, zircon, and micas, confirms this conclusion; mineral composition data for sediments at Site 142 (von Rad and Rösch, 1972) reaffirm it.

\section{BRAZIL BASIN}

Sediments at Site 355 consist of two components: terrigenous and chemogenic-diagenetic (Fe-Mn nodules, carbonates, and zeolites, among others). Quartz, green and yellow micas, and muscovite are predominant among light terrigenous minerals (Table 2 ), and magnetite, ilmenite, hornblende, and biotite prevail among heavy terrigenous minerals (Table 3 ). Some minerals characteristic of the Amazon suite-epi- 


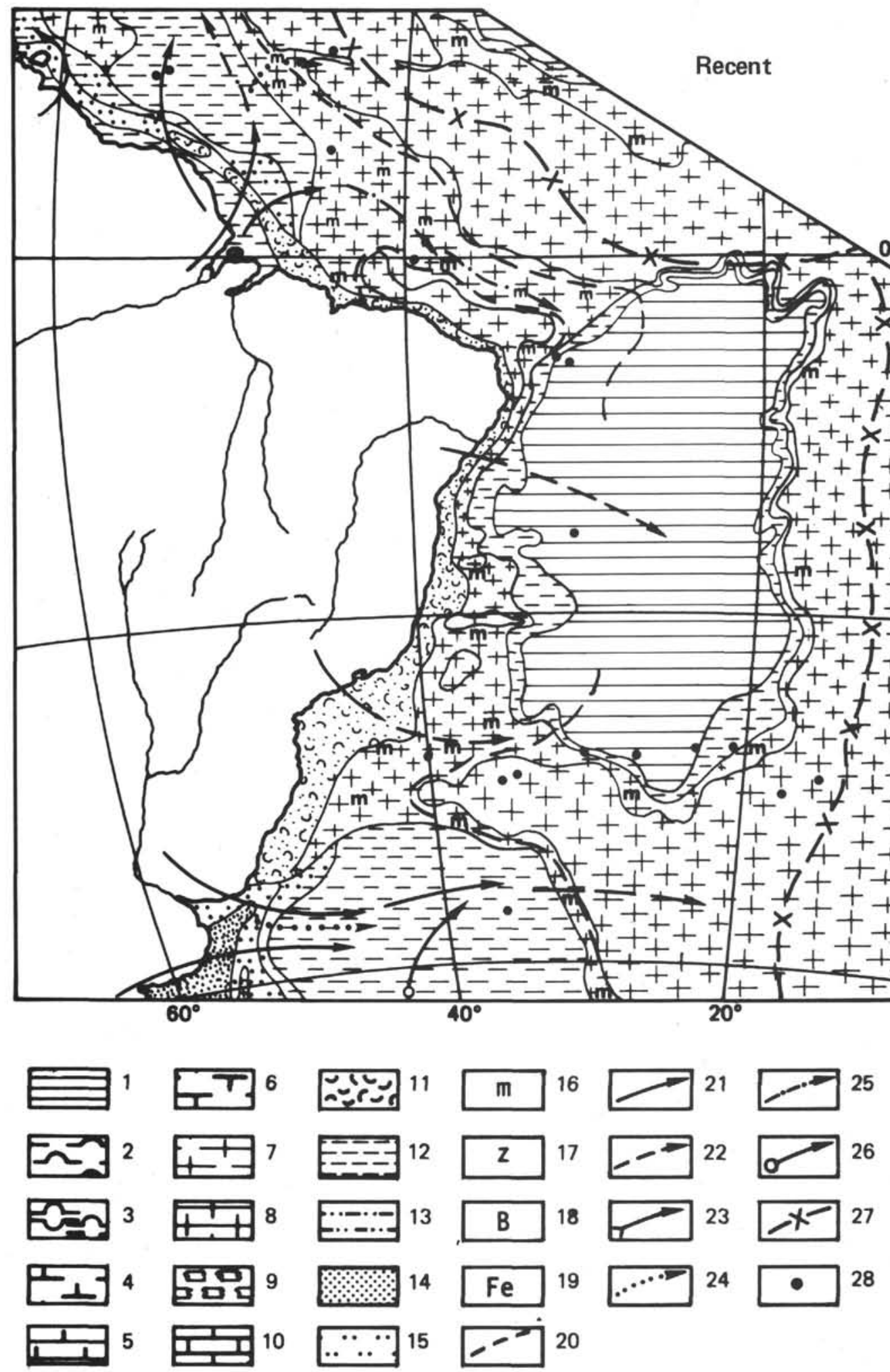

Figure 1b. Bottom sediments in the western South Atlantic in different stages of the Cenozoic, based on the data of deep-sea drilling: recent sediments. Legend: 1-pelagic clay; 2-diatom mud; 3-siliceous mud; 4-coccolith mud; 5-coccolith chalk; 6-foraminifer mud; 7-coccolith foraminifer mud; 8-foraminifer coccolith chalk; 9-calcareous mud; 10-limistone; 11-shell sediments; 12-clays; 13-terrigenous mud; 14-sands; 15-large aleurites; 16-marly deposits; 17-admixture of zeolites; 18-barite; 19-sulphides; 20-boundary of guiding influence of terrigenous material; 21-main directions of terrigenous material supply; 22-secondary directions of terrigenous material migrations; 23-volcaniclastic material supply; 24-directions of turbidity currents; 25-migration of sedimentary material supplied by bottom currents; 26supply of Antarctic iceberg material; 27-axial line of the Mid-Atlantic Ridge; 28-positions of sites. 


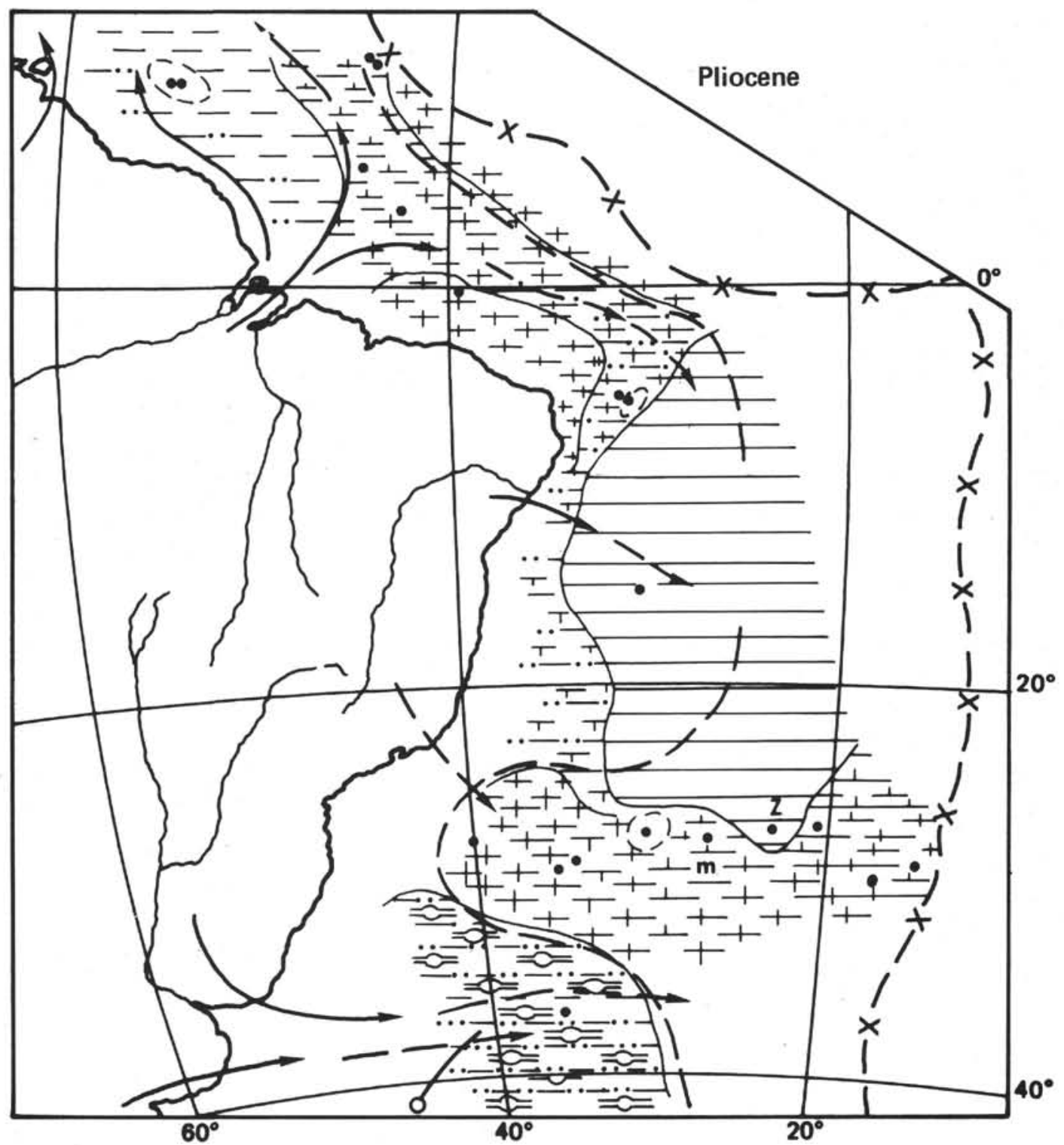

Figure 1c. Bottom sediments in the western South Atlantic in different stages of the Cenozoic, based on the data of deep-sea drilling: Pliocene. See Figure Ib for legend.

dote-zoisite, zircon, apatite, pyroxenes, and others -are scarce or lacking in the Brazil Basin.

Mineral composition of the Plio-Pleistocene sediments is very close to the average composition of Recent sediments in the Brazil Basin (Shurko, 1968). This basin receives sediment from a separate Brazilian terrigenous mineralogic province (Figure 3), the Brazilian Precambrian Shield, consisting of acid eruptive rocks and metamorphic rocks.

In Plio-Pleistocene sediments from Site 355, the heavy subfractions are strikingly large, owing to concentration not of clastic minerals, as at Site 353, but of authigenic constituents (Fe-Mn nodules and iron hydroxides). High concentration of these constituents is typical of Recent oxidized pelagic muds (Emelyanov et al., 1975). Heavy minerals are scarce in the greenish gray zeolitic pelagic muds of the Eocene, and those present are generally sulphides.

X-ray diffraction analysis of samples from Site 355 (Table 5) shows quartz contents ranging from $4 \%$ to about $18 \%: 17.7 \%$ in the Plio-Pleistocene samples, Miocene 4 to $16 \%$, and Eocene 5 to $12 \%$. Plagioclases occur in all the Tertiary sediments, potassic feldspars only in some sequences. Quartz-to-feldspar ratio is often greater than 1, sometimes greater than 2; such values characterize denudation products of the equatorial humid zone, where chemical weathering is active. Quartz content in samples from Sites 23 and 24 ranges from $7.4 \%$ to $78.3 \%$ of the crystalline fraction, or $40 \%$ on the average (Rex and Murray, 1970)-much more than in sediments at Site 355 . This is because Sites 23 and 24 are closer to the continent than Site 355 . High contents of potassic feldspars and plagioclases also occur in sediments at Sites 23 and 24, but the quartz-tofeldspar ratio is usually greater than 2-3.

Turbidites and high sedimentation rates $(\approx 5$ $\mathrm{cm} / 1000$ years) characterize deposits at Site 355 (Figure $3)$. In the upper part of the core (Miocene), turbidites are generally of bioclastic origin. They may therefore be associated with slumping on the continental slope and 


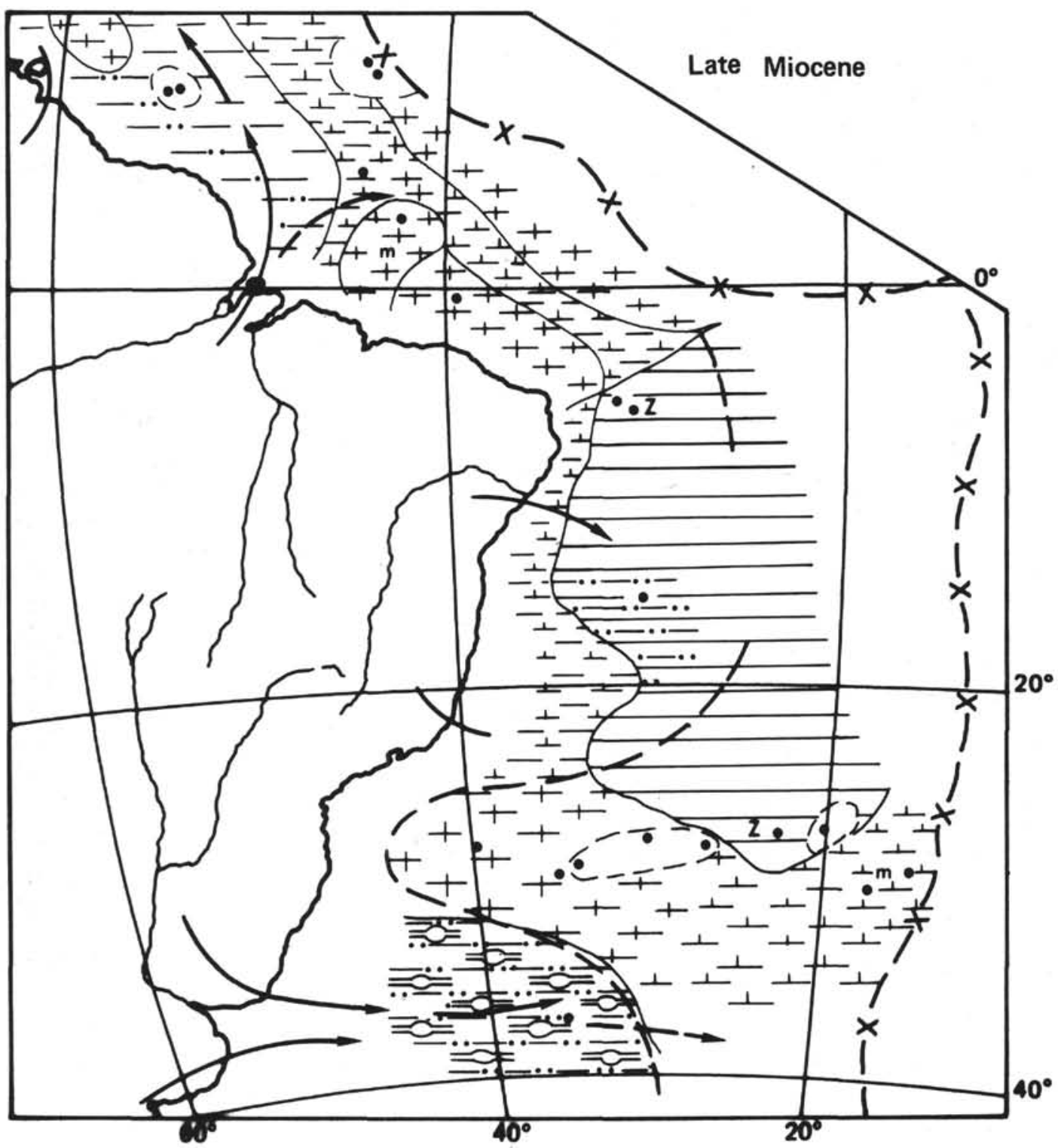

Figure 1d. Bottom sediments in the western South Atlantic in different stages of the Cenozoic, based on the data of deep-sea drilling: late Miocene. See Figure $1 \mathrm{~b}$ for legend.

underwater rises, areas where biogenic calcareous sediments were presumably accumulating in the Miocene. In lower and upper Eocene sediments, turbidites are terrigenous, evidently derived from the continental shelves. The mineral compositions of turbidites was not studied.

\section{SaO PaUlo Plateau}

Although Site 356 is near the continent, the content of terrigenous material in its sediments seldom exceeds $50 \%$. Both terrigenous and biogenic (calcareous and siliceous) materials accumulated there at a high rate (Figure 3).

In Cenozoic sediments at this site, quartz makes up 2 to $12 \%$, plagioclases 0 to $3 \%$, potassic feldspars 0 to $4 \%$ (Table 4). Quartz-to-feldspar ratio is usually high ( $>2$ 3). Quartz is also common in the coarse aleurite fraction, along with clastic minerals. Clastic minerals of the heavy subfraction include magnetite-ilmenite, hornblende, garnet, zircon, chlorite, and muscovite and other minerals (Table 3 ). The same minerals occur in Recent sands and in sediments of the continental slope-that is, within the so-called mineralogic provinces of Brazil and the Patagonian pampas and environs (Etchichury and Remiro, 1963). From this, we conclude that the clastic part of the Site 356 sediments formed from detritus from adjacent parts of South America (Precambrian shield of eastern Brazil and Tertiary traps).

Material from slumped Cretaceous deposits occurs in Pliocene sediments of Hole 356 (Cores 19, 24, and 25). They were presumably derived from the São Paulo Ridge (Site 356 report, this volume).

\section{RIO GRANDE RISE}

Sediments at Site 357 are generally calcareous biogenic material. The content of terrigenous material is minimal (Figure 3 ). 


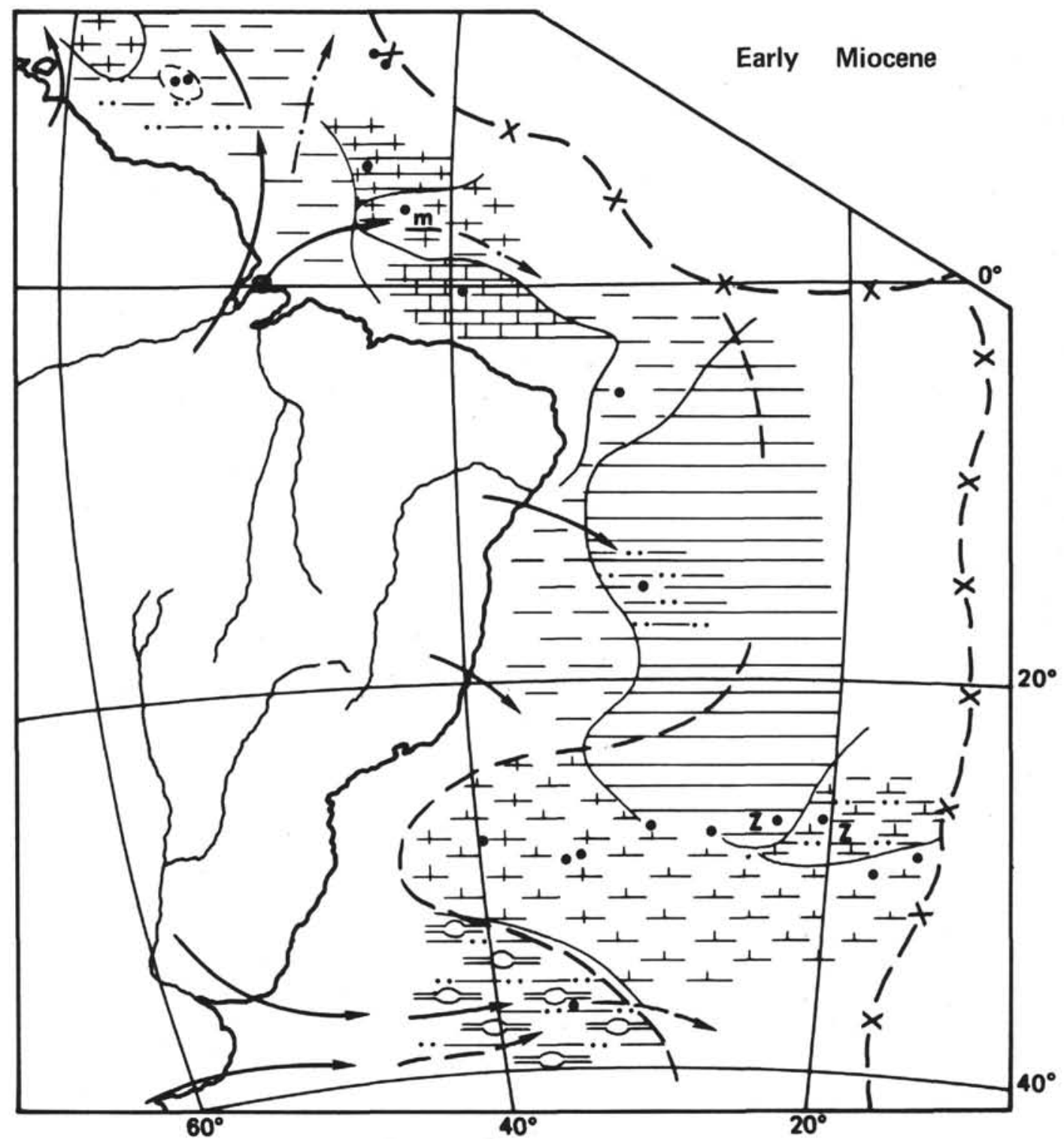

Figure 1e. Bottom sediments in the western South Atlantic in different stages of the Cenozoic, based on the data of deep-sea drilling: early Miocene. See Figure $1 b$ for legend.

The quartz content (on a carbonate-free basis) in Cenozoic sediments varies from 0 to $38.5 \%$, plagioclases 0 to $52.7 \%$, potassic feldspars 0 to $19.1 \%$. The highest feldspar contents occur in sediments of the Paleocene and early Eocene. Total feldspar content is often higher than the quartz content, resulting in a quartz-to-feldspar ratio either less than 1 or about 1 . This is not usual for terrigenous sediments. Volcanic rocks buried under Tertiary sediments of the South American continental margin seem to have been the chief sources of terrigenous material in the Paleoceneearly Eocene. In the middle Eocene, terrigenous contribution to sediment formation was insignificant.

The source of terrigenous material was different in the Oligocene, Miocene, and Pleistocene, as is evident in the high quartz contents of sediments of this period, their almost complete lack of potassic feldspars, and their increased illite contents (Table 5). The ratio of quartz to feldspar is usually greater than 1. Large quantities of montmorillonite persist, however.

Heavy minerals in the fraction 0.1 to $0.05 \mathrm{~mm}$ are usually scant. Most frequent (Table 3 ) are magnetiteilmenite, garnet, hornblende, zircon, clinopyroxenes, epidote-zoisite, and muscovite-ie., the same minerals that occur in sediments of the Brazilian coast (Etchichury and Remiro, 1963). This again, indicates that the clastic part of the Cenozoic section was derived from erosion of the South American land mass.

Differences in mineral compositions of the Cenozoic sediments indicate that a volcanic island or ridge, which connected the Rio Grande Rise with South America and served as a principal source of clastic and clay materials, existed before the Eocene (Site 357 report, this volume).

In the Maestrichtian or early Eocene, this source disappeared, and biogenic and chemogenic sedimentation 


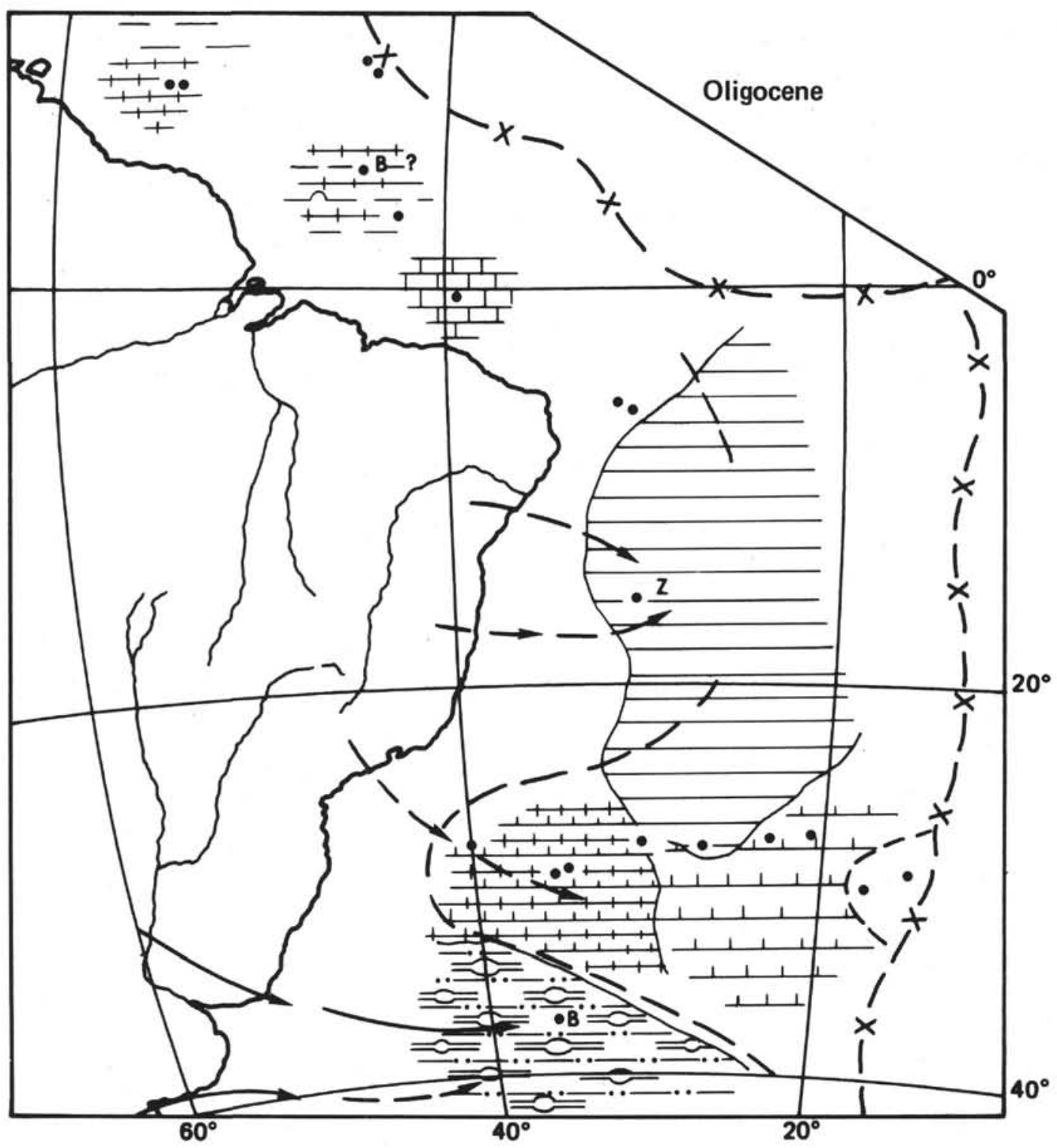

Figure 1f. Bottom sediments in the western South Atlantic in different stages of the Cenozoic, based on the data of deep-sea drilling: Oligocene. See Figure $1 b$ for legend.

(limestone, chalk, dolomite) gained ascendancy; the sediment accumulation rate dropped to $0.3 \mathrm{~cm} / 1000$ years.

Sediments rich in siliceous biogenic matter occur in the Eocene. Deposition of calcareous biogenic material, without abundant siliceous material, prevailed in the Oligocene-Pleistocene. The source of clastic and muddy materials was South America.

\section{ARGENTINE BASIN}

Terrigenous material dominates in the sediments at Site 358. Clay minerals, plagioclases, orthoclases, and quartz occur in varying proportions.

The quartz-to-feldspar ratio is usually greater than 1.5 in the lower Paleocene sediments. Illite and montmorillonite are the chief clay minerals (Table 5). Apatite, zircon, garnet, ilmenite, hornblende, and other terrigenous minerals occur in the heavy subfraction 0.1 -
$0.05 \mathrm{~mm}$ (Table 3 ), and flocculent clay dominates the light subfraction (Table 2).

The composition of the terrigenous part of the Eocene sediment is very different: feldspars are often absent, illite dwindles, montmorillonite prevails.

In deposits from the Oligocene to the Pleistocene, the mineral content changes again. Plagioclases and potassic feldspars are abundant; the ratio of quartz to feldspar decreases (usually $<1$ ); illite is more abundant than montmorillonite; kaolinite and cristobalite occur. Ilmenite, hornblende, garnet, epidote-zoisite, zircon, sphene, and other minerals occur frequently in the aleurite fraction (0.1-0.05 mm) of clastic material.

It is evident, then, that the source of clastic materials and clay minerals changed twice since the early Paleocene. From the Oligocene to the present, the source has remained essentially unchanged. This source appears to be the complex of volcanogenic rocks of the 


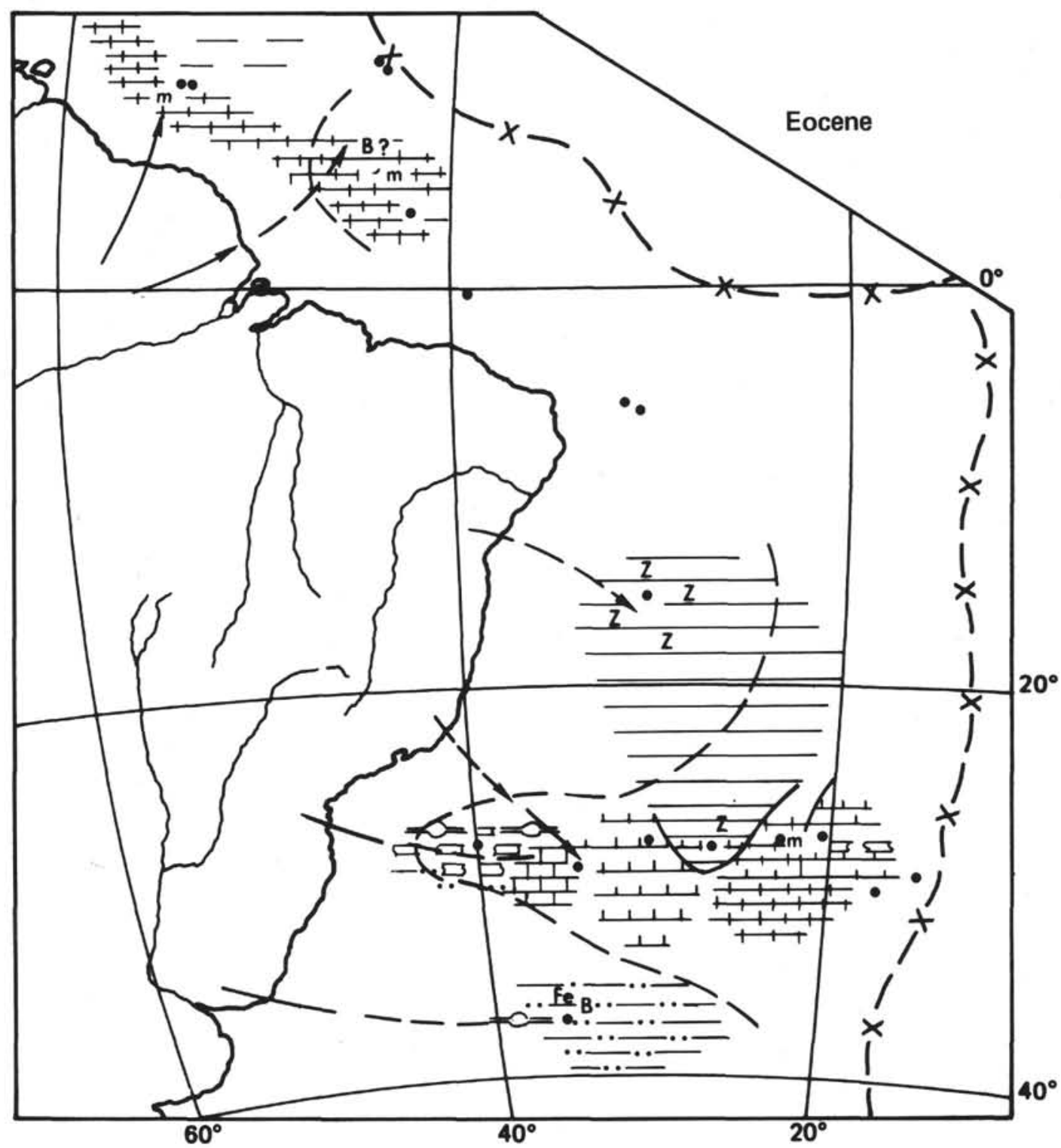

Figure 1g. Bottom sediments in the western South Atlantic in different stages of the Cenozoic, based on the data of deep-sea drilling: Eocene. See Figure 16 for legend.

Paraná river basin, where the largest trappean field on earth-about 2000 by 1000 kilometers-is situated. The Paraná River now drains this field; perhaps in the Tertiary, some pre-Paraná river existed which emptied into the Atlantic.

Basic and acid plagioclases, clay flocci, and volcanic material prevail in the alluvium of the modern La Plata and in clastic material of the Patagonia shelf sediments (Etchichury and Remiro, 1960, 1963; Emelyanov et al., 1975). The heavy subfraction consits of augite, magnetite, epidote, hypersthene, green and brown hornblende, and garnet. Recent (Shurko, 1968, 1971) and Oligocene-Pleistocene sediments of the Argentine Basin have roughly similar compositions.

In the Quaternary Period, sedimentary material entered the Argentine Basin from three sources: La Plata River discharge; the southern part of Argentina: and the Antarctic, as glacial debris (Biscaye, 1965;
Groot et al., 1967; Biscaye and Dash, 1971; Krinsley et al., 1973). In the Oligocene-Miocene, the principal sources were southern Argentina and the La Plata River.

\section{CONCLUSION}

From the beginning of the Cenozoic Era to the present (60-70 m.y.), accumulation of terrigenous material has contributed significantly to the overall sedimentation process in the western South Atlantic, although it has varied in space and time, as shown by Leg 39 data (Figure 3).

In the Paleocene (Figure $1 \mathrm{H}$ ), terrigenous deposits formed at the continental slope off Brazil (Site 24) and in the Brazil Basin, where material was supplied not only from erosion of the continent, but also from bottom erosion; brecciated layers of Upper Cretaceous calcareous rock in the sequence at Site 355 testify to 


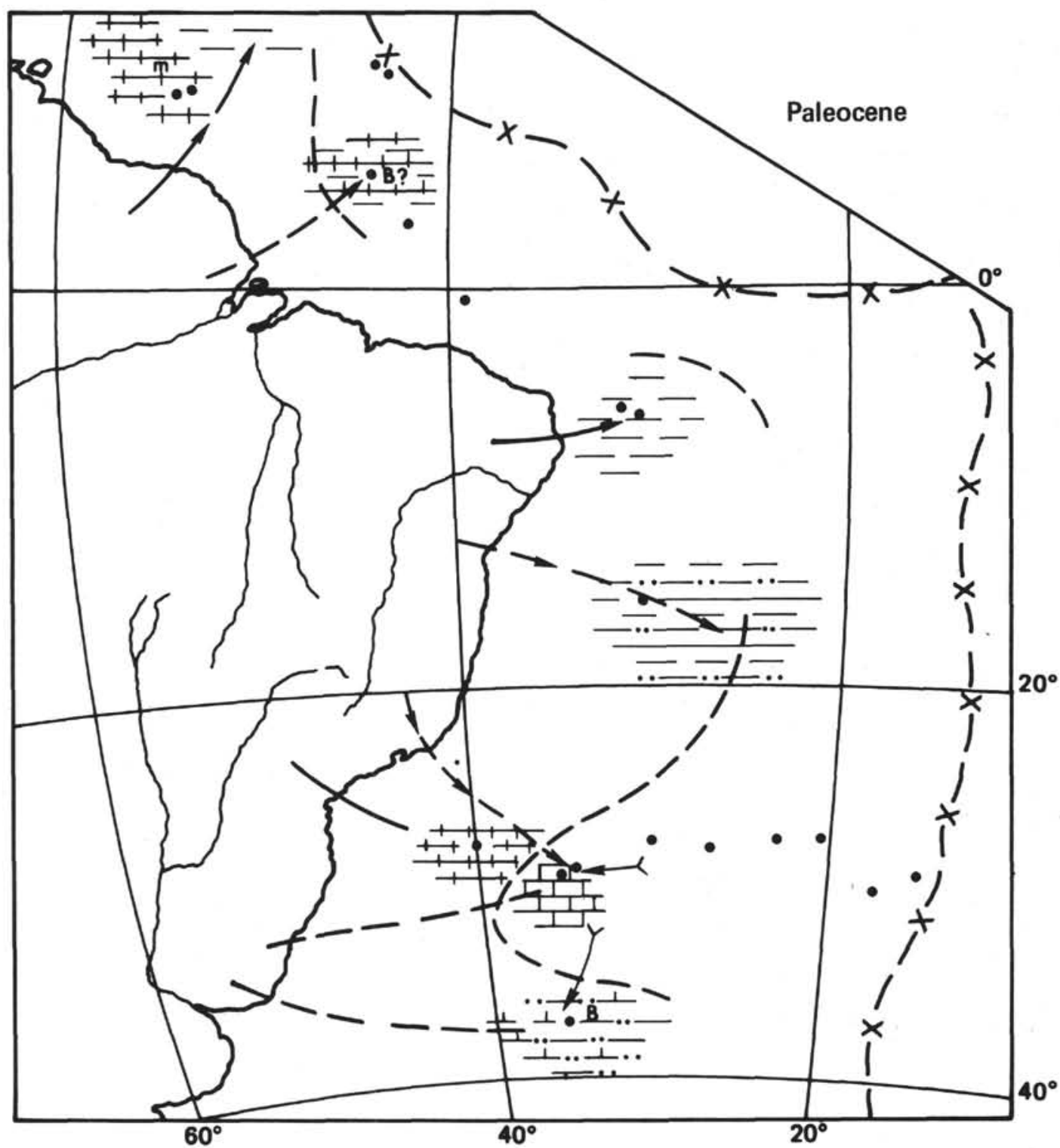

Figure 1h. Bottom sediments in the western South Atlantic in idfferent stages of the Cenozoic, based on the data of deep-sea drilling: Paleocene. See Figure $1 b$ for legend.

this. The amount of terrigenous material in the Brazil Basin declined toward the end of the Paleocene.

In the Argentine Basin, heavy accumulation of calcareous biogenic material accompanied deposition of terrigenous material. Minimal accumulation of terrigenous material in the Paleocene occurred at the Rio Grande Rise, the São Paulo Plateau, and the Guiana Basin (Ceará Rise, Site 354). Paleocene sediments at the Ceará Rise are highly calcareous, and those at the Rio Grande Rise (Site 357) are calcareous with a pronounced admixture of siliceous biogenic material. Except at the São Paulo Plateau, sediment accumulation rates were low, 0.03 to $0.3 \mathrm{~cm} / 1000$ years.

In the Eocene (Figure 1G), terrigenous sedimentation increased in the western South Atlantic. Pelagic clays consisting primarily of terrigenous components, with a notable admixture of zeolites and sometimes of siliceous material, accumulated in the Brazil Basin at relatively high rates $(5 \mathrm{~cm} / 1000$ years). The content of terrigenous components, inversely proportional to the content of calcareous material, also increased in sediments of the Argentine Basin. $\mathrm{CaCO}_{3}$ content here is $30 \%$ to $60 \%$ in lower Eocene deposits, and less than $10 \%$ in the upper Eocene. The terrigenous material is principally clay minerals. Almost the same sedimentation pattern existed at the São Paulo Plateau. Quantities of terrigenous sediment greater than those of the Paleocene entered the Guiana Basin, and, added to biogenic material, resulted in higher sediment accumulation rates.

In the Oligocene (Figure 1F), terrigenous material continued to play an important but diminished role in the Brazil and Argentine basins. Accumulation of the Oligocene pelagic clays was very slow in the Brazil Basin $(0.2 \mathrm{~cm} / 1000$ years $)$; terrigenous material presumably was derived from the same sources as in the Eocene, but entered the basin in considerably reduced 
TABLE 1

Grain-size Composition of Bottom Sediments from Leg 39 (in \%)

\begin{tabular}{|c|c|c|c|c|c|c|}
\hline \multirow[b]{2}{*}{$\begin{array}{c}\text { Sample } \\
\text { (Interval in } \mathrm{cm} \text { ) }\end{array}$} & \multicolumn{6}{|c|}{ Diameter of Particles (mm) } \\
\hline & $>0.1$ & $\begin{array}{l}0.1- \\
0.05\end{array}$ & $\begin{array}{l}0.05- \\
0.01\end{array}$ & $\begin{array}{l}0.01- \\
0.005\end{array}$ & $\begin{array}{l}0.005- \\
0.001\end{array}$ & $<0.001$ \\
\hline \multicolumn{7}{|l|}{ Hole 353} \\
\hline $2-1,120-122$ & 5.33 & 2.33 & 55.87 & 9.99 & 16.49 & 9.99 \\
\hline $3-2,4-5$ & 51.34 & 35.03 & 10.54 & - & - & - \\
\hline $3-2,70-72$ & 80.70 & 13.17 & 4.09 & - & - & - \\
\hline $3-2,130-132$ & 89.82 & 6.80 & 1.69 & - & - & - \\
\hline $3-2,145-147$ & 13.85 & 8.20 & 11.54 & 10.59 & 29.22 & 26.59 \\
\hline \multicolumn{7}{|l|}{ Hole 353A } \\
\hline $1-1,62-64$ & 0.25 & 0.17 & 4.90 & 13.94 & 38.94 & 41.81 \\
\hline $1-2,120-122$ & 0.07 & 0.07 & 15.21 & 15.36 & 38.50 & 30.79 \\
\hline \multicolumn{7}{|l|}{ Site 354} \\
\hline $1-2,55$ & 6.88 & 1.63 & 16.30 & 6.88 & 47.83 & 20.47 \\
\hline $2, \mathrm{CC}$ & 8.91 & 2.45 & 17.04 & 13.34 & 51.62 & 6.65 \\
\hline $3-2,120$ & 14.87 & 4.47 & 11.78 & 42.37 & 23.88 & 2.63 \\
\hline $4-3,100$ & 0.95 & 0.89 & 19.62 & 30.41 & 43.11 & 5.02 \\
\hline $4-6,110$ & 5.07 & 2.86 & 12.28 & 54.86 & 22.42 & 2.51 \\
\hline $5-1,71-73$ & 0.88 & 1.10 & 9.80 & 25.22 & 47.88 & 15.13 \\
\hline $6-3,104$ & 12.16 & 4.50 & 14.64 & 37.00 & 26.46 & 5.24 \\
\hline $7-4,137$ & 20.16 & 10.99 & 46.42 & - & - & - \\
\hline \multicolumn{7}{|l|}{ Site 355} \\
\hline $1-4,73-75$ & $\operatorname{tr}$ & $\operatorname{tr}$ & 2.73 & 26.56 & 30.93 & 39.78 \\
\hline $1-5,60-62$ & $\operatorname{tr}$ & $\mathrm{tr}$ & 2.37 & 22.06 & 31.46 & 44.11 \\
\hline $1-6,80-82$ & 0.10 & 0.10 & 4.69 & 36.25 & 27.08 & 31.77 \\
\hline $9-2,97-99$ & 0.11 & 0.32 & 5.19 & 20.53 & 49.31 & 24.55 \\
\hline \multicolumn{7}{|l|}{ Hole 356} \\
\hline $2-1,111-113$ & 29.29 & 12.72 & 12.47 & 9.12 & 21.26 & 15.15 \\
\hline $3-2,15-17$ & 1.05 & 4.29 & 38.17 & 24.71 & 21.18 & 10.59 \\
\hline $4-3,15-17$ & 0.27 & 1.52 & 31.51 & 23.37 & 23.37 & 19.96 \\
\hline $5-4,50-53$ & 18.58 & 20.00 & 24.83 & 16.59 & 3.41 & 16.59 \\
\hline $6-4,100-103$ & 0.62 & 3.80 & 11.29 & 17.56 & 45.69 & 21.05 \\
\hline $7-4,40-43$ & 1.70 & 0.85 & 10.31 & 16.74 & 50.24 & 20.15 \\
\hline $8-2,50-53$ & 0.73 & 2.09 & 8.99 & 14.11 & 45.87 & 28.21 \\
\hline $9-2,108-110$ & 1.43 & 3.38 & 10.76 & 13.01 & 45.49 & 25.92 \\
\hline $10-4,104-106$ & 31.55 & 5.57 & 12.49 & 11.99 & 23.98 & 14.42 \\
\hline $11-2,13-17$ & 1.86 & 1.86 & 7.64 & 6.39 & 50.62 & 31.62 \\
\hline $17-4,40-43$ & $\operatorname{tr}$ & 7.05 & 9.25 & 13.95 & 32.60 & 37.15 \\
\hline $26-2,9-11$ & 1.66 & 2.20 & 12.49 & 3.65 & 45.47 & 34.53 \\
\hline $29-2,100-102$ & 0.18 & 3.08 & 15.31 & 2.81 & 33.70 & 44.93 \\
\hline $29-6,22-24$ & 1.21 & 3.69 & 14.93 & 8.52 & 44.26 & 27.39 \\
\hline $31-5,87-89$ & 2.05 & 3.63 & 8.37 & 8.56 & 42.98 & 34.42 \\
\hline $33-2,98-100$ & 0.51 & 2.32 & 13.51 & 11.97 & 38.22 & 33.46 \\
\hline \multicolumn{7}{|l|}{ Hole 356A } \\
\hline $1-4,68-70$ & 0.48 & 0.73 & 36.03 & 31.32 & 15.72 & 15.72 \\
\hline $2-5,40-42$ & 3.52 & 3.52 & 25.70 & 25.18 & 25.18 & 16.90 \\
\hline \multicolumn{7}{|l|}{ Site 357} \\
\hline $1-2,123-126$ & 43.91 & 19.07 & 12.42 & 6.15 & 6.15 & 12.30 \\
\hline $6-5,64-67$ & 12.58 & 12.15 & 21.94 & 21.37 & 21.30 & 10.65 \\
\hline $8-4,50-53$ & 4.93 & 6.01 & 24.19 & 26.58 & 29.43 & 8.86 \\
\hline $9-3,70-73$ & 4.61 & 5.92 & 18.60 & 19.06 & 43.66 & 8.15 \\
\hline $13-5,84-87$ & 5.64 & 14.07 & 16.23 & 14.76 & 39.42 & 9.89 \\
\hline $40-4,45-46$ & $\operatorname{tr}$ & 0.74 & 1.85 & 22.55 & 22.37 & 52.49 \\
\hline $41-2,79-80$ & 0.18 & 1.27 & 2.90 & 23.96 & 15.97 & 55.72 \\
\hline $51-6,125-126$ & 5.32 & 0.69 & 16.90 & 28.94 & 28.94 & 19.21 \\
\hline
\end{tabular}


TABLE 1 - Continued

\begin{tabular}{|c|c|c|c|c|c|c|}
\hline \multirow[b]{2}{*}{$\begin{array}{c}\text { Sample } \\
\text { (Interval in } \mathrm{cm} \text { ) }\end{array}$} & \multicolumn{6}{|c|}{ Diameter of $(\mathrm{mm})$ particles } \\
\hline & $>0.1$ & $\begin{array}{l}0.1- \\
0.05\end{array}$ & $\begin{array}{l}0.05- \\
0.01\end{array}$ & $\begin{array}{l}0.01- \\
0.005\end{array}$ & $\begin{array}{l}0.005- \\
0.001\end{array}$ & $<0.001$ \\
\hline \multicolumn{7}{|l|}{ Site 358} \\
\hline $1-3,79-80$ & $\operatorname{tr}$ & 0.13 & 20.18 & 12.61 & 25.22 & 41.87 \\
\hline $3-2,75-77$ & 0.07 & 0.13 & 14.14 & 22.09 & 35.96 & 27.61 \\
\hline $3-5,75-77$ & 0.28 & 0.35 & 13.81 & 15.64 & 33.66 & 36.26 \\
\hline $4-1,108-110$ & $\operatorname{tr}$ & 1.50 & 40.42 & 9.58 & 9.88 & 38.62 \\
\hline $5-2,75-77$ & 0.12 & 0.87 & 39.00 & 18.76 & 15.03 & 26.21 \\
\hline $6-2,124-126$ & 0.14 & 0.73 & 31.54 & 19.33 & 14.53 & 33.72 \\
\hline $7-1,63-65$ & 0.42 & 1.27 & 34.46 & 18.22 & 22.74 & 22.88 \\
\hline $8-1,121-123$ & $\operatorname{tr}$ & 0.29 & 21.72 & 15.60 & 31.19 & 31.20 \\
\hline $9-2,62-64$ & 0.16 & 0.16 & 17.09 & 26.68 & 29.31 & 26.60 \\
\hline $10-3,72-74$ & 0.09 & 0.17 & 22.57 & 24.67 & 24.67 & 27.82 \\
\hline $11-3,7-9$ & 0.24 & 0.42 & 8.72 & 12.69 & 52.67 & 25.27 \\
\hline $11-4,91-93$ & 0.13 & 0.81 & 42.43 & 28.24 & 9.46 & 18.92 \\
\hline $12-3,73-75$ & 0.31 & 0.21 & 74.66 & 9.95 & 4.92 & 9.95 \\
\hline $12-4,63-65$ & 0.14 & 0.56 & 16.50 & 30.49 & 30.49 & 21.82 \\
\hline $13-1,107-109$ & 0.16 & 0.24 & 19.55 & 22.05 & 30.37 & 27.62 \\
\hline $14-2,136-138$ & 0.11 & 0.22 & 12.42 & 18.55 & 42.72 & 25.97 \\
\hline $15-1,67-69$ & 0.08 & 0.08 & 20.36 & 19.18 & 30.15 & 30.15 \\
\hline $16-2,99-101$ & 0.19 & 0.38 & 45.95 & 16.64 & 20.28 & 16.57 \\
\hline \multicolumn{7}{|l|}{ Hole 359} \\
\hline $1-3,52-54$ & 26.35 & 24.68 & 15.77 & 13.22 & 13.22 & 6.66 \\
\hline $2-6,100-102$ & 41.19 & 17.32 & 16.14 & 9.49 & 6.36 & 9.49 \\
\hline $3-1,94-96$ & 15.24 & 19.27 & 32.10 & 16.69 & 8.31 & 8.39 \\
\hline $3-3,119-121$ & 57.88 & 10.74 & 13.06 & 4.52 & 4.64 & 9.16 \\
\hline $3-4,43-45$ & 16.27 & 10.57 & 29.96 & 9.58 & 9.58 & 24.03 \\
\hline $3-4,68-70$ & 58.80 & 8.97 & 17.59 & 3.63 & 3.63 & 7.38 \\
\hline $3-5,79-81$ & 10.53 & 17.68 & 36.37 & 11.81 & 11.81 & 11.81 \\
\hline \multicolumn{7}{|l|}{ Hole 359A } \\
\hline $1-4,29-31$ & 30.08 & 22.56 & 14.80 & 11.60 & 9.28 & 11.68 \\
\hline $2-5,111-113$ & 28.78 & 25.87 & 15.60 & 11.93 & 7.90 & 9.92 \\
\hline
\end{tabular}

quantity. In the Argentine Basin, by contrast, increased contributions of siliceous material, together with the terrigenous contribution, resulted in higher overall accumulation rates in the Oligocene. In neither the Oligocene nor the late Eocene did calcareous material deposit in the Argentine Basin. Sedimentation seems to have been generally controlled by the influence of cold currents from the Antarctic (Site 358 report, this volume). The other important source of terrigenous material for this area was the continental drainage region of a pre-Paraná river.

Deposition of calcareous material continued at the Rio Grande Rise. Terrigenous contributions came from the same sources, but in reduced amounts.

At the Ceará Rise, accumulation of biogenic material proceeded at a high rate in the Oligocene, and accumulation of terrigenous material was reduced. $\mathrm{CaCO}_{3}$ typically makes up $50 \%$ to $60 \%$ of Oligocene sediments at this site, and the admixture of zeolites is significant. Clay minerals account for 5 to $20 \%$ of the sediment, and quartz occurs in the aleurite fraction.

In the Miocene (Figures 1D, 1E), non-calcareous terrigenous sediments were deposited in the Brazil Basin and on the continental slope off Brazil (Site 24). Calcareous biogenic deposits prevail in other areas. Non-calcareous muds in the Argentine Basin contain large quantities of siliceous material; the main component is clay, $50 \%$ to $60 \%$ on the average, and the siliceous biogenic content varies from 25 to $50 \%$. Miocene accumulation rates were high.

Accumulation rates in the Brazil Basin increased from a minimum in the early Miocene to higher values in the late Miocene. Layers of bioclastic turbidites, with significantly changed $\mathrm{CaCO}_{3}$ content, occur in Miocene sediments. The clay content is variable ( 5 to $70 \%$ ); other terrigenous minerals, of which quartz in principal ( 0 to $10 \%)$, are scarce.

In the Miocene, accumulation of biogenic material combined with the deposition of terrigenous material in the Guiana Basin, with fluctuations in the early and late Miocene (Figures 1D, 1E).

In the Pliocene, deposition of terrigenous material was rapid in the Brazil Basin, less intensive in the Argentine Basin. Although accumulation rates in the two basins were the same $(\approx 2 \mathrm{~cm} / 1000$ years $)$, much more siliceous biogenic material was deposited in the Argentine Basin. Pliocene sediments in the Brazil Basin are terrigenous, and contain not more than $5 \%$ biogenic detritus.

Accumulation of terrigenous material was scant at the São Paulo Plateau and the Rio Grande Rise. Low sedimentation rates and high $\mathrm{CaCO}_{3}$ contents characterize the Pliocene deposits at Sites 356, 21, and 22.

Heavy accumulation of biogenic material continued in the Guiana Basin during the Pliocene. Terrigenous material with a mineral composition indicating an 
TABLE 2

Mineralogic Composition of Bottom Sediments From Leg 39 (light-mineral content, in \%)

\begin{tabular}{|c|c|c|c|c|c|c|c|c|c|c|c|c|}
\hline \multirow[b]{3}{*}{ Depth (m) } & \multirow{3}{*}{$\begin{array}{c}\text { Sample } \\
\text { (Interval in } \mathrm{cm} \text { ) }\end{array}$} & \multicolumn{8}{|c|}{ Terrigenous } & \multirow[b]{2}{*}{ 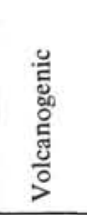 } & \multirow[b]{2}{*}{ 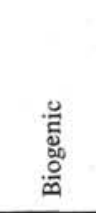 } & \multirow[b]{2}{*}{ 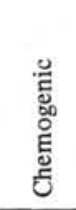 } \\
\hline & & \multirow{2}{*}{ 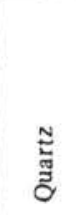 } & \multirow{2}{*}{ 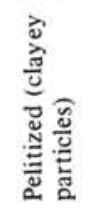 } & \multirow{2}{*}{ 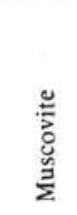 } & \multirow{2}{*}{ 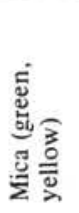 } & \multirow{2}{*}{ 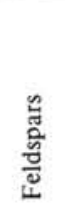 } & \multirow{2}{*}{ 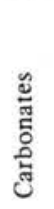 } & \multirow{2}{*}{ 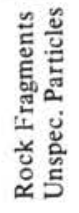 } & \multirow[b]{2}{*}{ Total } & & & \\
\hline & & & & & & & & & & Total & Total & Total \\
\hline \multicolumn{2}{|l|}{ Hole 353} & & & & & & & & & & & \\
\hline 119.7 & $2-1,120-122$ & 4.8 & 4.4 & - & 6.9 & 8.2 & - & - & 24.3 & - & 75.4 & - \\
\hline 262.5 & $3-2,4-5$ & 43.3 & 43.6 & 12.0 & - & 0.4 & - & - & 99.3 & - & 0.4 & 0.4 \\
\hline 263.2 & $3-2.70-72$ & 50.4 & 42.9 & 6.4 & - & - & - & - & 99.7 & - & - & - \\
\hline 263.8 & $3-2,130-132$ & 41.4 & 47.0 & 10.8 & - & 0.7 & - & - & 99.9 & - & 0.3 & - \\
\hline 264.0 & $3-2,145-147$ & 56.9 & 30.4 & 6.2 & - & 1.8 & - & - & 95.3 & - & 4.0 & - \\
\hline Hole $353 \mathrm{~A}$ & & & & & & & & & & & & \\
\hline & $1-1.62-64$ & 53.4 & 28.0 & 9.8 & - & 0.7 & 0.5 & 0.7 & 93.1 & 1.0 & 5.8 & - \\
\hline & $1-2.120-122$ & 26.2 & 8.6 & 53.4 & - & - & - & - & 88.2 & - & 11.8 & - \\
\hline Site 354 & & & & & & & & & & & & \\
\hline 5.5 & $1-2.55$ & 0.3 & - & - & - & - & - & - & 0.3 & - & 99.7 & - \\
\hline 54.5 & 2. $\mathrm{CC}^{\circ}$ & - & - & 8.4 & - & - & - & 0.4 & 9.2 & - & 91.3 & - \\
\hline 101.2 & $3-2.120$ & & - & - & - & - & - & - & - & - & 100.0 & - \\
\hline 144.0 & $4-3.100$ & - & $\ldots$ & - & - & - & - & - & - & - & 99.7 & 0.3 \\
\hline 148.6 & $4-6.110$ & & & 0.2 & - & - & - & - & 0.2 & - & 99.7 & - \\
\hline 194.2 & $5-1.71-73$ & 0.3 & & - & - & - & - & - & 0.3 & - & 99.7 & - \\
\hline 243.5 & $6-3.104$ & & & - & .. & - & - & - & - & - & 100.0 & - \\
\hline 288.4 & 74.137 & & & - & - & - & - & - & - & - & 100.0 & - \\
\hline Site 355 & & & & & & & & & & & & \\
\hline 58.2 & $1-4 \cdot 73-75$ & 5.7 & 54.4 & 3.9 & 0.4 & 3.5 & - & - & 70.9 & 0.9 & 29.5 & 1.7 \\
\hline 59.6 & $1-5,6(1-62$ & 54.0 & 19.1 & 7.5 & 0.6 & - & - & - & 81.2 & - & 18.2 & 0.6 \\
\hline 61.3 & $1-6.801-82$ & 19.1 & 10.6 & 37.6 & 1.7 & 5.0 & 0.6 & - & 74.6 & 0.6 & 24.7 & - \\
\hline 321.5 & $9 \cdot 2.97 .99$ & 0.3 & & 89.5 & & 0.3 & - & - & 90.1 & - & 6.6 & 1.3 \\
\hline Hole 356 & & & & & & & & & & & - & \\
\hline 10.6 & $2-1.111 .113$ & 0.7 & & - & - & .. & - & - & 0.7 & - & 99.3 & - \\
\hline 39.7 & $3-2.15 \cdot 17$ & 0.3 & 0.3 & - & - & - & - & 0.3 & 0.9 & - & 99.1 & - \\
\hline 60.2 & $4-3,15-17$ & 0.3 & & & - & -- & - & - & 0.3 & - & 99.0 & - \\
\hline 90.5 & $5-4.5(1)-53$ & 0.7 & 6.6 & 0.7 & 0.3 & - & - & - & 8.6 & - & 91.3 & - \\
\hline 119.5 & $6.4 .101(1-103$ & 0.3 & 8.6 & 0.3 & 0.3 & - & - & - & 9.5 & - & 89.5 & - \\
\hline 137.5 & $7-4.4(1)-43$ & 0.3 & 0.6 & - & 0.6 & - & - & - & 1.5 & - & 98.4 & - \\
\hline 169.5 & $8-2.50)-53$ & 0.3 & 19.9 & - & 0.7 & - & - & - & 20.9 & - & 78.9 & - \\
\hline 198.6 & $9-2.108-110$ & & 20.0 & & -- & - & - & - & 20.0 & - & 80.0 & $\overline{0}$ \\
\hline 227.1 & $10-4,104-106$ & 1.6 & 5.5 & - & - & - & - & - & 7.1 & - & 90.9 & 0.3 \\
\hline 243.7 & $11-2.13-17$ & - & 4.6 & - & - & - & - & - & 4.6 & - & 95.1 & - \\
\hline 299.4 & $17-4.40-43$ & 0.9 & 95.0 & - & - & - & - & - & 95.9 & - & 2.4 & 0.3 \\
\hline 381.6 & $26-2.9-11$ & 0.6 & 0.3 & - & 1.0 & - & - & - & 1.9 & - & 97.7 & - \\
\hline 411.0 & $29-2.100-102$ & 0.3 & 2.0 & - & - & - & - & - & 2.3 & - & 97.7 & - \\
\hline 416.2 & $29-6.22-24$ & 1.0 & 0.3 & 1.3 & 1.0 & - & - & - & 3.6 & - & 94.7 & - \\
\hline 443.9 & $31-5.87-89$ & 0.3 & 0.3 & 0.5 & 0.3 & - & - & - & 1.4 & - & 98.3 & - \\
\hline 487.0 & $33-2.98-100$ & 1.6 & 0.6 & - & 0.3 & - & - & - & 2.5 & - & 93.8 & 2.3 \\
\hline Hole 356A & & & & & & & & & & & & \\
\hline 24.2 & $14,68-70$ & 2.2 & 0.3 & - & 0.6 & 0.6 & - & - & 3.1 & - & 96.1 & - \\
\hline 34.9 & $2-5,40-42$ & 0.9 & - & - & - & - & - & - & 0.9 & - & 99.1 & - \\
\hline Site 357 & & & & & & & & & & & & \\
\hline 2.7 & $1-2,123-126$ & 0.3 & - & - & - & - & - & - & 0.3 & - & 99.7 & - \\
\hline 53.2 & $6-5,64-67$ & - & - & - & - & - & - & - & - & - & 100.0 & - \\
\hline 70.5 & $8-4,50-53$ & - & - & - & - & - & - & - & - & - & 100.0 & - \\
\hline 78.7 & $9-3,70-73$ & - & - & - & - & - & - & - & - & - & 100.0 & - \\
\hline 138.9 & $13-5,84-87$ & - & 0.3 & - & - & - & - & - & 0.3 & - & 99.7 & - \\
\hline 697.5 & $40-4,45-46$ & - & 88.1 & - & - & - & - & - & 88.1 & - & 12.0 & - \\
\hline 705.3 & $41-2,79-80$ & - & 97.6 & 0.3 & - & - & - & - & 97.9 & - & 2.0 & - \\
\hline 796.2 & $51-6,125-126$ & 0.7 & 83.2 & - & 0.3 & - & - & - & 84.2 & - & 13.9 & 2.0 \\
\hline
\end{tabular}


TABLE 2 - Continued

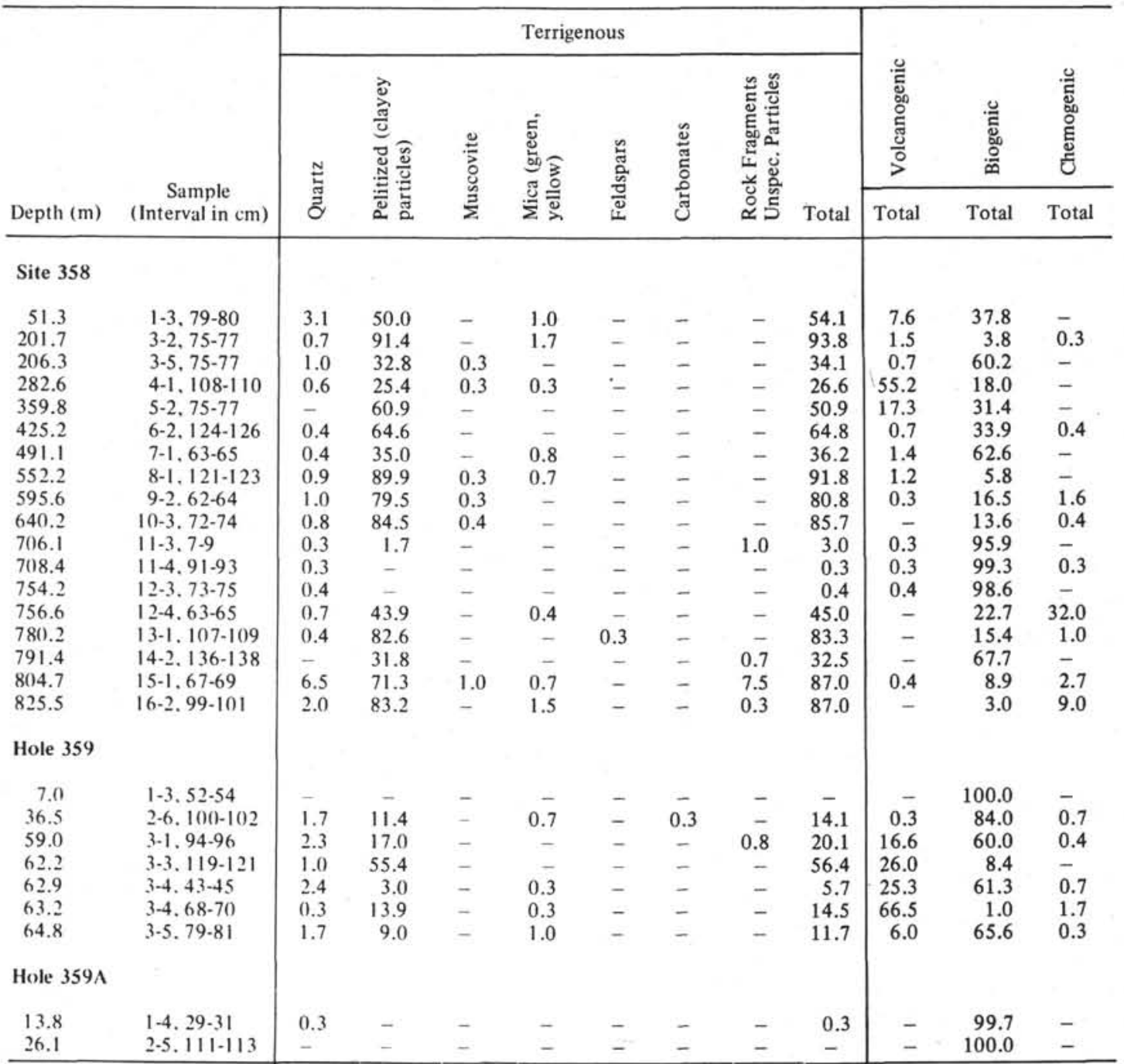

Amazon source did not extend into the central and southeastern parts of the basin.

In the Pleistocene, abundant terrigenous material entered the Guiana Basin and particularly the Vema Fracture Zone (Sites 353, 26), where a thick Pleistocene turbidite sequence was deposited. A similar picture appears in the southeastern Guiana Basin, where Amazon sediment was being deposited.

Accumulation of terrigenous material dominated during the Pleistocene in the Brazil and Argentine basins, and has continued to do so up to the present (Figure 1B).

We have seen that the supply of terrigenous material to the western South Atlantic was continuous during the Cenozoic, and that this supply frequently provided the principal component of the total sediment budget, especially in the Brazil and Argentine basins. The pattern of accumulation of terrigenous sediments changed repeatedly through the Cenozoic. The changes were dependent primarily upon local factors.

\section{ACKNOWLEDGMENTS}

The authors thank Peter R. Supko, the head of the Leg 39, and Yuri P. Neprochnov for giving us the opportunity to take part in the study of samples from all sites of Leg 39. Analysts were as follows: Granulometry, G.V. Zhuravlev and A.I. Panikhina; Microscopy, N.G. Lozovaya; X-ray Diffraction, K.P. Zangalis and A.S. Kozhevnikov.

\section{REFERENCES}

Bader, R.G. et al., 1970. Site 23. In Bader, R.G., Gerard, R.D., et al., Initial Reports of the Deep Sea Drilling Project, Volume 4: Washington (U.S. Government Printing Office), p17-35.

Biscaye, P., 1965. Mineralogy and sedimentation of recent deep-sea clay in the Atlantic Ocean and adjacent seas and oceans: Geol. Soc. Am. Bull., v. 76, p. 803-831.

Biscaye, P.E. and Dash, E.J., 1971. The rubidium, strontium, strontium-isotope system in deep-sea sediments. Argentine basin: J. Geophys. Res., v. 76, p. 5087-5096.

Demerara Coastal Investigation, 1962. Report on siltation of Demerara Barr Channel and coastal erosion in British Guiana: The Netherlands.

Emelyanov, E.M., Lisitzin, A.P., and Ilyin, A.V., 1975. Tipy donnykh osadkov Atlanticheskogo okeana (Types of bottom sediments of the Atlantic Ocean): Results of Researches of the International Geophysical Projects, Kaliningrad, p. 1-570.

Emelyanov, E.M. and Kharin, G.S., 1974. Osadkoobrazovaniye v Gvianskoy i Severo-Amerikanskoy kotlovinakh v svyasi s tvyordymi vynosami Amazonki i Orinoko (Sedimentation in the Guiana and North 
TABLE 3

Mineralogic Composition of Bottom Sediments from Leg 39 (Heavy Minerals of 0.1-0.05 mm Fraction; sp. gr.> 2.9)

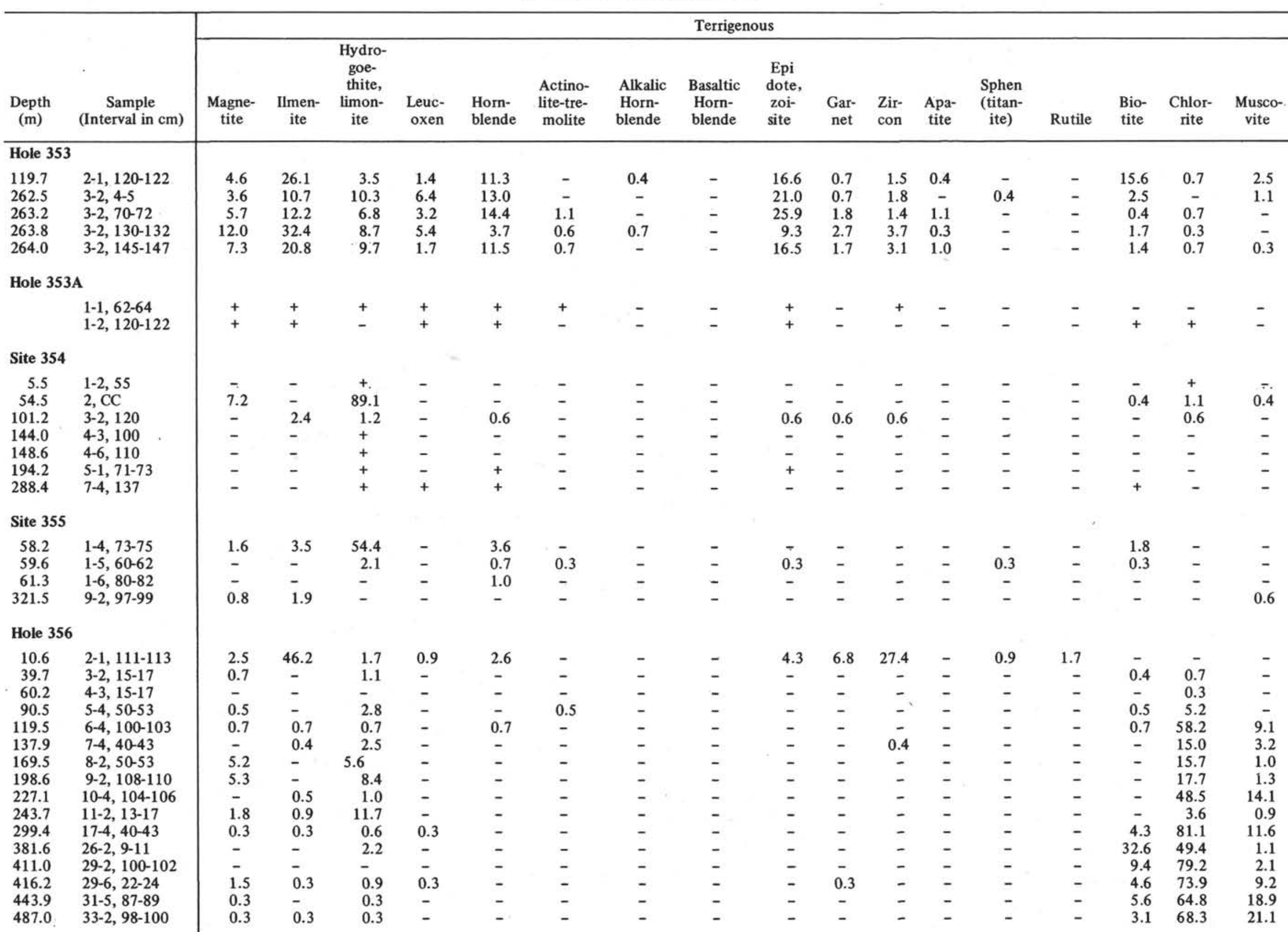




\begin{tabular}{|c|c|c|c|c|c|c|c|c|c|c|c|c|c|c|c|c|c|c|}
\hline \multicolumn{19}{|c|}{ Hole $356 \mathrm{~A}$} \\
\hline 24.2 & $1-4,68-70$ & 3.0 & 0.5 & 5.6 & - & 1.0 & - & - & - & 1.0 & 0.5 & - & - & - & - & - & 0.5 & - \\
\hline 34.9 & $2-5,40-42$ & 0.5 & - & 1.4 & - & 0.7 & - & - & - & - & 0.7 & - & - & - & - & - & 1.4 & 1.4 \\
\hline \multicolumn{19}{|c|}{ Site 357} \\
\hline 2.7 & $1-2,123-126$ & 3.3 & 11.9 & 3.4 & 11.9 & 8.5 & - & 1.7 & - & 1.7 & 6.8 & 22.0 & - & - & - & - & - & 3.4 \\
\hline 53.2 & $6-5,64-67$ & 0.7 & 1.3 & - & - & - & - & - & - & - & - & - & - & - & - & - & - & - \\
\hline 70.5 & $8-4,50-53$ & 1.5 & - & 2.3 & - & - & - & - & - & - & - & - & - & - & - & - & - & - \\
\hline 78.7 & $9-3,70-73$ & - & - & 1.1 & - & - & _- & - & - & - & 1.1 & - & - & - & - & - & - & - \\
\hline 138.9 & $13-5,84-87$ & - & 0.6 & 1.9 & 0.6 & 0.6 & - & - & - & - & - & - & - & - & - & - & - & - \\
\hline 697.5 & $40-4,45-46$ & + & - & + & - & - & - & - & - & - & - & - & - & - & - & - & - & - \\
\hline 705.3 & $41-2,79-80$ & 4.6 & - & - & - & - & - & - & - & - & - & - & 1.5 & 12.3 & - & - & 1.5 & - \\
\hline 796.2 & $51-6,125-126$ & 0.3 & - & - & - & - & - & - & - & - & 0.4 & - & - & 0.4 & - & - & - & 0.4 \\
\hline \multicolumn{19}{|c|}{ Site 358} \\
\hline 51.3 & $1-3,79-80$ & - & - & - & - & 0.4 & - & - & - & 0.4 & 0.8 & 0.4 & - & - & 0.4 & - & - & - \\
\hline 201.7 & $3-2,75-77$ & - & + & - & - & + & - & - & - & + & - & - & - & - & + & + & - & - \\
\hline 206.3 & $3-5,75-77$ & - & - & - & - & - & - & - & - & - & - & 0.4 & - & - & - & - & - & - \\
\hline 282.6 & $4-1,108-110$ & - & 1.2 & 6.1 & 1.2 & 1.2 & 1.2 & - & - & - & - & 3.7 & 1.2 & 1.2 & - & 7.3 & 1.2 & 2.4 \\
\hline 359.8 & $5-2,75-77$ & - & - & 0.5 & - & - & - & - & - & - & 0.5 & - & - & - & - & 1.0 & 0.5 & 0.5 \\
\hline 425.2 & $6-2,124-126$ & - & - & - & - & - & 0.4 & - & - & - & 0.4 & - & - & 0.4 & - & - & - & - \\
\hline 491.1 & $7-1,63-65$ & - & - & 0.7 & - & - & - & - & - & 1.1 & 1.1 & 0.4 & - & - & - & - & - & - \\
\hline 552.2 & $8-1,121-123$ & - & 0.4 & - & - & - & - & - & - & - & 0.4 & - & - & - & - & - & - & - \\
\hline 595.6 & $9-2,62-64$ & - & 0.6 & - & - & 0.6 & - & - & - & 1.3 & - & 0.6 & - & - & - & - & - & - \\
\hline 640.2 & $10-3,72-74$ & - & - & 0.3 & - & - & - & - & - & 0.3 & 0.7 & 0.7 & - & - & - & - & - & - \\
\hline 706.1 & $11-3,7-9$ & 0.3 & 0.3 & 0.3 & - & - & - & - & - & - & 0.3 & 0.3 & 0.3 & - & - & - & .. & - \\
\hline 708.4 & $11-4,91-93$ & - & 0.4 & - & - & 0.4 & - & - & - & - & - & - & - & - & - & - & - & - \\
\hline 754.2 & $12-2,73-75$ & 0.4 & -. & - & - & 1.1 & - & - & - & 0.4 & 0.4 & 0.7 & - & - & - & - & - & - \\
\hline 755.6 & $12-4,63-65$ & - & 1.0 & 1.0 & - & - & - & - & - & - & 0.5 & - & 0.5 & - & - & - & - & - \\
\hline 780.2 & $13-1,107-109$ & - & 0.8 & 0.8 & 0.8 & 0.8 & - & - & - & - & 0.8 & 0.4 & 0.4 & - & - & - & - & - \\
\hline 791.4 & $14-2,136-138$ & - & $\begin{array}{l}0.0 \\
-\end{array}$ & $\begin{array}{l}0.0 \\
1.0\end{array}$ & $\begin{array}{l}0.0 \\
-\end{array}$ & 0.0 & - & - & - & - & $\begin{array}{l}0.0 \\
-\end{array}$ & 0.4 & 0.3 & - & - & - & - & - \\
\hline 804.7 & $15-1,67-69$ & - & 1.2 & 1.2 & - & - & - & - & - & - & 2.4 & - & - & - & - & 1.2 & 1.2 & - \\
\hline 825.5 & $16-2,99-101$ & - & 0.9 & 1.8 & 0.9 & - & - & - & - & - & 0.9 & - & 0.9 & - & - & 1.8 & 7.9 & - \\
\hline \multicolumn{19}{|c|}{ Hole 359} \\
\hline 7.0 & $1-3,52-54$ & 3.2 & 20.7 & 6.6 & 2.5 & 0.8 & - & - & - & 5.8 & 7.4 & 5.8 & 1.6 & 1.6 & 0.8 & - & 2.5 & 2.5 \\
\hline 36.5 & $2-6,100-102$ & 0.8 & 15.9 & 20.0 & 3.4 & - & - & - & - & - & - & 1.7 & - & - & - & - & - & - \\
\hline 59.0 & $3-1,94-96$ & - & 2.2 & 1.0 & - & - & - & 0.4 & 1.1 & - & - & - & 0.7 & - & - & 0.4 & - & 0.4 \\
\hline 62.2 & $3-3,119-121$ & 0.3 & 9.9 & 1.1 & - & - & - & - & - & 0.3 & - & - & - & - & - & 0.3 & 0.3 & - \\
\hline 62.9 & $3-4,43-45$ & 0.3 & 7.9 & 1.7 & 0.3 & - & - & - & - & 0.6 & - & - & - & - & - & - & - & 0.3 \\
\hline 63.2 & $3-4,68-70$ & - & 9.4 & - & - & - & - & - & - & - & - & 0.4 & - & - & - & - & - & - \\
\hline 64.8 & $3-5,79-81$ & - & 1.8 & 2.9 & - & - & 0.4 & 0.7 & 0.4 & 0.4 & - & - & - & - & - & - & 0.4 & - \\
\hline \multicolumn{19}{|c|}{ Hole 359A } \\
\hline 13.8 & $1-4,29-31$ & - & 7.5 & 2.3 & 0.6 & 2.3 & - & - & - & 0.6 & 0.6 & 2.9 & - & - & - & - & - & - \\
\hline 26.1 & $2-5,111-113$ & 2.1 & 7.1 & 5.0 & 1.7 & 0.4 & - & - & - & - & 0.4 & - & - & - & - & - & - & 0.4 \\
\hline
\end{tabular}

Note: $-=$ missing; $+=$ trace $;++=$ present 
TABLE 3 - Continued

\begin{tabular}{|c|c|c|c|c|c|c|c|c|c|c|c|c|c|c|c|}
\hline \multirow[b]{2}{*}{$\begin{array}{l}\text { Depth } \\
(\mathrm{m})\end{array}$} & \multirow[b]{2}{*}{$\begin{array}{l}\text { Sample } \\
\text { (Interval } \\
\text { in } \mathrm{cm} \text { ) }\end{array}$} & \multicolumn{14}{|c|}{ Terrigenous } \\
\hline & & Tourmaline & $\begin{array}{l}\text { Staur- } \\
\text { olite }\end{array}$ & $\begin{array}{l}\text { Chlor- } \\
\text { itoid }\end{array}$ & Kyanite & $\begin{array}{l}\text { Others, Andalu- } \\
\text { site, Orthite, } \\
\text { (topaz) }\end{array}$ & $\begin{array}{c}\text { Rock } \\
\text { Fragments }\end{array}$ & $\begin{array}{l}\text { Monoclinic } \\
\text { Pyroxene }\end{array}$ & $\begin{array}{l}\text { Rhombic } \\
\text { Pyroxene }\end{array}$ & $\begin{array}{l}\text { Olivine, } \\
\text { Idding- } \\
\text { site }\end{array}$ & Total & $\begin{array}{l}\text { Volcano- } \\
\text { genic }\end{array}$ & Biogenic & $\begin{array}{l}\text { Chemo- } \\
\text { genic }\end{array}$ & $\begin{array}{l}\text { Heavy Mine- } \\
\text { rals in fr. } \\
0.1-0.05 \mathrm{~mm} \\
\quad \text { (in } \% \text { ) }\end{array}$ \\
\hline \multicolumn{16}{|c|}{ Hole 353} \\
\hline 119.7 & $2-1,120-122$ & 1.4 & 0.4 & 0.4 & - & - & 0.4 & 3.8 & 1.5 & - & 92.2 & 4.2 & - & 2.8 & 3.3 \\
\hline 262.5 & $3-2,4-5$ & 1.4 & - & - & - & - & - & 15.6 & 1.8 & - & 90.3 & 9.2 & - & 0.4 & 2.2 \\
\hline 263.2 & $3-2,70-72$ & 2.2 & 0.4 & - & - & - & - & 6.8 & 10.1 & 0.4 & 94.6 & - & - & 0.8 & 5.8 \\
\hline 263.8 & $3-2,130-132$ & 0.3 & - & - & 0.3 & - & - & 5.7 & 7.7 & - & 95.5 & 4.3 & - & - & 14.2 \\
\hline 264.0 & $3-2,145-147$ & - & - & 0.3 & 0.4 & 0.6 & - & 8.0 & 8.0 & - & 93.8 & 4.9 & - & 1.0 & 2.4 \\
\hline \multicolumn{16}{|c|}{ Hole 353A } \\
\hline & $1-1,62-64$ & - & - & - & - & - & - & - & - & - & - & + & - & + & 3.3 \\
\hline & $1-2,120-122$ & - & - & - & - & - & - & - & - & - & - & + & - & + & 3.0 \\
\hline \multicolumn{16}{|c|}{ Site 354} \\
\hline 5.5 & $1-2,55$ & - & - & - & - & - & - & - & - & - & + & + & - & + & 0.1 \\
\hline 54.5 & $2, \mathrm{CC}$ & - & - & - & - & - & - & - & - & - & 98.2 & - & 1.1 & 0.4 & 0.4 \\
\hline 101.2 & $3-2,120$ & - & - & - & - & - & - & - & - & - & 6.6 & - & 92.1 & 0.6 & 0.2 \\
\hline 144.0 & $4-3,100$ & - & - & - & - & - & - & - & - & - & - & - & ++ & - & 0.4 \\
\hline 148.6 & $4-6,110$ & - & - & - & - & - & - & - & - & - & - & - & ++ & - & \\
\hline 194.2 & $5-1,71-73$ & - & - & - & - & - & - & - & - & - & - & - & ++ & - & \\
\hline 288.4 & $7-4,137$ & - & - & - & - & - & - & - & - & - & - & - & ++ & - & \\
\hline \multicolumn{16}{|c|}{ Site 355} \\
\hline 58.2 & $1-4,73-75$ & - & - & - & - & - & - & - & - & - & 64.9 & 7.0 & 14.0 & 10.0 & 11.0 \\
\hline 59.6 & $1-5,60-62$ & - & - & - & - & 0.3 & - & - & - & - & 4.3 & 0.3 & 39.5 & 55.6 & 60.2 \\
\hline 61.3 & $1-6,80-82$ & - & - & - & - & 0.3 & - & - & - & - & 1.3 & - & 1.3 & 97.4 & 44.6 \\
\hline 321.5 & $9-2,97-99$ & - & - & - & - & - & - & - & - & - & 3.3 & - & 3.8 & 92.6 & $\begin{array}{r}44.0 \\
0.9\end{array}$ \\
\hline \multicolumn{16}{|c|}{ Hole 356} \\
\hline 10.6 & $2-1,111-113$ & - & - & - & - & - & - & - & - & - & 95.11 & - & 1.7 & 3.4 & \\
\hline 39.7 & $3-2,15-17$ & - & - & - & - & - & - & - & - & - & 2.9 & - & 85.1 & 12.0 & 0.2 \\
\hline 90.5 & $5-4,50-53$ & - & - & - & - & - & - & - & - & - & 0.3 & - & 1.0 & 98.6 & 4.1 \\
\hline 119.5 & $6-4,110-103$ & - & - & - & - & - & - & 0.3 & - & - & 71.4 & - & 2.7 & 25.9 & 0.54 \\
\hline 137.9 & $7-4,40-43$ & - & - & - & - & - & - & - & - & - & 21.5 & - & 3.2 & 75.3 & 1.78 \\
\hline 169.5 & $8-2,50-53$ & - & - & - & - & - & - & - & - & - & 27.5 & - & 21.6 & 50.8 & 0.40 \\
\hline 198.6 & $9-2,108-110$ & - & - & - & - & - & - & - & - & - & 32.7 & - & 31.9 & 35.4 & 1.27 \\
\hline 227.1 & $10-4,104-106$ & - & - & - & - & - & - & - & - & - & 64.1 & - & 33.8 & 2.0 & 0.44 \\
\hline 243.7 & $11-2,13-17$ & - & - & - & - & - & - & - & - & - & 83.0 & - & 81.1 & - & 0.86 \\
\hline 299.4 & $17-4,40-43$ & - & - & - & - & - & - & - & - & - & 98.5 & - & - & 1.2 & 0.48 \\
\hline 381.6 & $26-2,9-11$ & - & - & - & - & - & - & - & - & - & 85.3 & - & 13.5 & 1.1 & 0.56 \\
\hline 411.0 & $29-2,100-102$ & - & - & - & - & - & - & 1.0 & - & - & 91.7 & 8.3 & 8.3 & - & 0.50 \\
\hline 416.2 & $29-6,22-24$ & - & - & - & - & - & - & - & - & - & 91.0 & - & 8.5 & 0.3 & 0.43 \\
\hline 443.9 & $31-5,87-89$ & - & - & - & - & - & - & - & - & - & 89.9 & 0.3 & 9.3 & 0.3 & 0.49 \\
\hline 487.0 & $33-2,98-100$ & - & - & - & - & 0.3 & - & - & - & - & 93.7 & - & 5.4 & 0.6 & 0.47 \\
\hline
\end{tabular}




\begin{tabular}{|c|c|c|c|c|c|c|c|c|c|c|c|c|c|c|c|}
\hline 24.2 & $1-4,68-70$ & - & - & - & - & - & - & - & - & - & 12.1 & - & 65.8 & 21.9 & 0.6 \\
\hline 34.9 & $2-5,40-42$ & - & - & - & - & - & - & - & - & - & 6.1 & - & 23.0 & 70.9 & 0.2 \\
\hline \multicolumn{16}{|c|}{ Site 357} \\
\hline 2.7 & $1-2,132-126$ & - & - & - & - & - & - & 1.7 & - & - & 76.3 & - & 22.0 & 1.7 & \\
\hline 53.2 & $6-5,64-67$ & - & - & - & - & - & - & - & - & - & 2.0 & 0.7 & 63.6 & 33.8 & \\
\hline 70.5 & $8-4,60-53$ & - & - & - & - & - & - & - & - & - & 3.8 & - & 93.2 & 3.0 & 0.3 \\
\hline 78.7 & $9-3,70-73$ & - & - & - & - & - & - & - & - & - & 2.2 & - & 87.0 & 10.9 & \\
\hline 138.9 & $13-5,84-87$ & - & - & - & - & - & - & - & - & - & 3.7 & - & 94.3 & 1.9 & \\
\hline 697.5 & $40-4,45-46$ & - & + & - & - & - & - & - & - & - & + & - & - & + & \\
\hline 705.3 & $41-2,79-80$ & - & - & - & - & - & - & - & - & - & 19.9 & 1.5 & - & 78.5 & 0.5 \\
\hline 796.2 & $51-6,125-126$ & - & - & 0.4 & - & - & - & - & - & - & 1.9 & - & - & 98.3 & 3.6 \\
\hline \multicolumn{16}{|c|}{ Site 358} \\
\hline 51.3 & $1-3,79-80$ & - & - & - & - & - & - & - & - & - & 2.4 & 1.2 & 0.4 & 95.9 & 4.8 \\
\hline 201.7 & $3-2,75-77$ & - & - & - & - & + & - & - & - & - & + & - & - & - & \\
\hline 206.3 & $3-5,77-77$ & - & - & - & - & - & - & - & - & - & 0.4 & 99.2 & 14.0 & 85.7 & 43.3 \\
\hline 282.6 & $4-1,108-110$ & - & - & - & - & - & - & - & - & - & 26.7 & - & 28.0 & 45.2 & 0.5 \\
\hline 359.8 & $5-2,75-77$ & - & - & - & - & - & - & - & - & - & 3.0 & 2.6 & 10.9 & 83.3 & 1.8 \\
\hline 425.2 & $6-2,124-126$ & - & - & - & - & - & - & - & - & - & 1.2 & - & 0.7 & 98.2 & 12.6 \\
\hline 491.1 & $7-1,63-65$ & - & - & - & - & - & - & - & - & - & 3.3 & 0.4 & 2.8 & 93.7 & 3.7 \\
\hline 552.2 & $8-1,121-123$ & - & - & - & - & - & - & - & - & - & 0.8 & - & 2.2 & 97.1 & 10.1 \\
\hline 595.6 & $9-2,62-64$ & 0.6 & - & - & - & - & - & - & - & - & 3.7 & - & 81.4 & 14.7 & 10.6 \\
\hline 640.2 & $10-3,72-74$ & - & - & - & - & - & - & - & - & - & 2.0 & - & 92.5 & 5.6 & 18.7 \\
\hline 706.1 & $11-3,7-9$ & - & - & - & - & - & - & - & - & - & 1.8 & - & 90.0 & 8.3 & 2.9 \\
\hline 708.4 & $11-4,91-93$ & - & - & - & - & - & - & - & - & - & 0.8 & - & 26.0 & 78.3 & 7.8 \\
\hline 754.2 & $12-2,73-75$ & - & - & - & - & - & - & - & - & - & 3.0 & - & 63.5 & 33.6 & 4.3 \\
\hline 755.6 & $12-4,63-65$ & - & - & - & - & - & - & - & - & - & 3.0 & - & 86.5 & 10.4 & 1.8 \\
\hline 780.2 & $13-1,107-109$ & 0.4 & - & - & - & - & - & - & - & - & 5.2 & - & 93.6 & 1.6 & 2.0 \\
\hline 791.4 & $14-2,136-138$ & - & - & - & - & - & - & - & - & - & 1.3 & - & 94.6 & 4.0 & 9.6 \\
\hline 804.7 & $15-1,67-69$ & - & - & - & - & - & - & - & - & - & 9.6 & 1.2 & 66.7 & 22.7 & 3.6 \\
\hline 825.5 & $16-2,99-101$ & - & - & - & - & - & - & - & - & - & 15.1 & - & 71.9 & 13.2 & 1.1 \\
\hline \multicolumn{16}{|c|}{ Hole 359} \\
\hline 7.0 & $1-3,52-54$ & - & - & - & - & - & - & - & - & - & 61.8 & 9.9 & 27.3 & - & 0.02 \\
\hline 36.5 & $2-6,100-102$ & - & - & - & - & - & - & 0.8 & - & - & 42.6 & 9.8 & 43.4 & 0.4 & 0.7 \\
\hline 59.0 & $3-1,94-96$ & - & - & - & 0.4 & 0.4 & 5.8 & 10.9 & - & 0.4 & 76.2 & 19.5 & 1.1 & 3.3 & 1.4 \\
\hline 62.2 & $3-3,119-121$ & - & - & - & - & 0.3 & 2.1 & 40.9 & - & - & 54.4 & 18.6 & 1.0 & 25.7 & 1.2 \\
\hline 62.9 & $3-4,43-45$ & - & - & - & - & - & - & 86.8 & - & - & 96.6 & 1.5 & - & 1.8 & 1.8 \\
\hline 64.8 & $3-5,79-81$ & - & - & - & - & - & 0.7 & 3.9 & - & - & 11.6 & 86.3 & 2.2 & - & 1.3 \\
\hline \multicolumn{16}{|c|}{ Hole 359A } \\
\hline 13.8 & $1-4,29-31$ & - & - & - & - & - & - & - & - & - & 17.4 & 9.8 & 72.8 & - & 0.04 \\
\hline 26.1 & $2-5,111-113$ & - & - & - & - & - & - & - & - & - & 17.1 & 10.4 & 72.1 & 0.4 & 0.04 \\
\hline
\end{tabular}

Note: $-=$ missing $++=$ trace $++=$ present 
TABLE 4

Content of Carbonate Minerals, Quartz, and Feldspars in Bottom Sediments from Leg 39 (in \%)

\begin{tabular}{|c|c|c|c|c|c|}
\hline \multirow{2}{*}{$\begin{array}{c}\text { Depth } \\
\text { (m) }\end{array}$} & \multirow{2}{*}{$\begin{array}{c}\text { Sample } \\
\text { (Interval in } \mathrm{cm} \text { ) }\end{array}$} & \multirow{2}{*}{$\begin{array}{c}\text { Total } \\
\text { Carbonates }\end{array}$} & \multicolumn{3}{|c|}{ Clastic Minerals } \\
\hline & & & Quartz & Plagioclase & K-Feldspar \\
\hline \multicolumn{6}{|c|}{ Hole 353} \\
\hline $\begin{array}{l}126.5 \\
263.7 \\
263.9\end{array}$ & $\begin{array}{l}2-3,50-52 \\
3-2,120-122 \\
3-2,142-144\end{array}$ & $\begin{array}{l}1.0 \\
1.0 \\
2.0\end{array}$ & $\begin{array}{l}12.5 \\
56.0 \\
27.0\end{array}$ & $\begin{array}{l}<4.0 \\
<5.0 \\
<4.0\end{array}$ & \\
\hline \multicolumn{6}{|c|}{ Hole 353A } \\
\hline 181.0 & $\begin{array}{l}1-2,91-94 \\
1, C C\end{array}$ & 1.0 & $\begin{array}{l}16.0 \\
58.0\end{array}$ & $\begin{array}{l}<2.0 \\
<6.0\end{array}$ & \\
\hline \multicolumn{6}{|c|}{ Hole 356} \\
\hline $\begin{array}{r}10.3 \\
39.8 \\
60.6 \\
91.0 \\
119.0 \\
138.0 \\
169.6 \\
198.5 \\
225.0 \\
244.8 \\
253.1 \\
273.8 \\
292.0 \\
299.5 \\
318.4 \\
353.7 \\
365.0 \\
365.9 \\
368.2 \\
372.8 \\
381.7 \\
408.8 \\
411.1 \\
416.3 \\
443.7 \\
487.0 \\
545.0 \\
654.3 \\
681.3 \\
701.4 \\
705.0 \\
734.1\end{array}$ & $\begin{array}{l}2-1,82-85 \\
3-2,28-30 \\
4-3,55-57 \\
5-4,101-103 \\
6-4,50-53 \\
7-4,50-53 \\
8-2,60-63 \\
9-2,98-100 \\
10-3,48-50 \\
11-2,129-131 \\
12-1,11-13 \\
14-1,25-27 \\
16-1,100-102 \\
17-4,50-53 \\
19-4,40-42 \\
23-2,70-72 \\
24-3,101-103 \\
24-4,35-37 \\
24-5,120-122 \\
25-2,30-33 \\
26-2,23-25 \\
29-2,30-32 \\
29-2,110-112 \\
29-6,30-32 \\
31-5,68-70 \\
33-2,94-97 \\
35-3,50-52 \\
38-3,82-84 \\
39-5,75-77 \\
40-6,42-44 \\
41-2,48-50 \\
44-2,110-112\end{array}$ & $\begin{array}{r}67.0 \\
52.0 \\
42.0 \\
52.0 \\
30.0 \\
24.0 \\
30.0 \\
36.0 \\
29.0 \\
16.0 \\
21.0 \\
31.0 \\
17.0 \\
44.0 \\
16.0 \\
38.0 \\
21.0 \\
70.0 \\
42.0 \\
50.0 \\
46.0 \\
8.0 \\
24.0 \\
50.0 \\
63.0 \\
45.0 \\
46.0 \\
45.0 \\
0.0 \\
2.0 \\
0.0 \\
26.0\end{array}$ & $\begin{array}{r}2.0 \\
5.0 \\
7.0 \\
5.0 \\
4.0 \\
5.0 \\
5.0 \\
4.0 \\
4.0 \\
5.0 \\
3.0 \\
3.0 \\
2.0 \\
4.0 \\
6.0 \\
5.0 \\
8.0 \\
4.0 \\
4.0 \\
4.0 \\
4.0 \\
12.0 \\
9.0 \\
6.0 \\
5.0 \\
6.0 \\
9.0 \\
7.0 \\
17.0 \\
21.0 \\
17.0 \\
18.0\end{array}$ & $\begin{array}{l}0.0 \\
1.0 \\
1.0 \\
1.0 \\
1.0 \\
1.0 \\
1.0 \\
1.0 \\
1.0 \\
1.0 \\
\text { tr. } \\
\text { tr. } \\
\text { tr. } \\
1.0 \\
2.0 \\
1.0 \\
1.0 \\
1.0 \\
1.0 \\
1.0 \\
1.0 \\
3.0 \\
2.0 \\
\text { tr. } \\
\text { tr. } \\
1.0 \\
1.0 \\
1.0 \\
2.0 \\
2.0 \\
2.0 \\
2.0\end{array}$ & $\begin{array}{l}0.0 \\
1.0 \\
0.0 \\
0.0 \\
0.0 \\
0.0 \\
0.0 \\
0.0 \\
0.0 \\
1.0 \\
\text { tr. } \\
0.0 \\
0.0 \\
0.0 \\
0.0 \\
0.0 \\
1.0 \\
0.0 \\
0.0 \\
0.0 \\
0.0 \\
4.0 \\
2.0 \\
\text { tr. } \\
\text { tr. } \\
1.0 \\
0.0 \\
0.0 \\
0.0 \\
0.0 \\
0.0 \\
0.0\end{array}$ \\
\hline \multicolumn{6}{|c|}{ Hole $356 \mathrm{~A}$} \\
\hline $\begin{array}{l}24.2 \\
35.1\end{array}$ & $\begin{array}{l}1-4,72-74 \\
2-5,55-57\end{array}$ & $\begin{array}{l}34.0 \\
43.0\end{array}$ & $\begin{array}{l}8.0 \\
7.0\end{array}$ & $\begin{array}{l}2.0 \\
2.0\end{array}$ & $\begin{array}{l}0.0 \\
0.0\end{array}$ \\
\hline \multicolumn{6}{|c|}{ Hole 359} \\
\hline $\begin{array}{l}6.4 \\
36.9 \\
58.2 \\
62.0 \\
62.8 \\
91.2\end{array}$ & $\begin{array}{l}1-3,91-141 \\
2-6,139-141 \\
3-1,15-17 \\
3-3,96-98 \\
3-4,26-28 \\
4-2,19-21\end{array}$ & $\begin{array}{r}74.0 \\
58.0 \\
47.0 \\
40.0 \\
<1.0 \\
3.0\end{array}$ & $\begin{array}{l}0.0 \\
1.0 \\
1.0 \\
1.0 \\
1.0 \\
0.0\end{array}$ & $\begin{array}{r}0.0 \\
1.0 \\
2.0 \\
2.0 \\
15.0 \\
\text { tr. }\end{array}$ & $\begin{array}{l}0.0 \\
0.0 \\
0.0 \\
0.0 \\
0.0 \\
0.0\end{array}$ \\
\hline \multicolumn{6}{|c|}{ Hole 359A } \\
\hline $\begin{array}{l}17.6 \\
17.6 \\
21.5\end{array}$ & $\begin{array}{l}1-6,108-110 \\
1-6,112-114 \\
2-2,104-106\end{array}$ & $\begin{array}{l}73.0 \\
72.0 \\
72.0\end{array}$ & $\begin{array}{l}0.0 \\
0.0 \\
0.0\end{array}$ & $\begin{array}{l}0.0 \\
0.0 \\
0.0\end{array}$ & $\begin{array}{l}0.0 \\
0.0 \\
0.0\end{array}$ \\
\hline
\end{tabular}


TABLE 5

X-ray Diffraction Analysis of Bulk Samples, Leg 39 (in percent from total crystalline components)

\begin{tabular}{|c|c|c|c|c|c|c|c|c|c|c|c|c|}
\hline \multirow[b]{2}{*}{$\begin{array}{c}\text { Sample } \\
\text { (Interval in } \mathrm{cm} \text { ) }\end{array}$} & \multicolumn{5}{|c|}{ Clay Minerals } & \multirow[b]{2}{*}{ Quartz } & \multirow[b]{2}{*}{$\begin{array}{l}\text { K-feld- } \\
\text { spar }\end{array}$} & \multirow[b]{2}{*}{$\begin{array}{l}\text { Plagio- } \\
\text { clase }\end{array}$} & \multirow[b]{2}{*}{$\begin{array}{l}\text { Cristo- } \\
\text { balite }\end{array}$} & \multirow[b]{2}{*}{$\begin{array}{l}\text { Clinop- } \\
\text { tilolite }\end{array}$} & \multirow{2}{*}{$\begin{array}{c}\text { Total } \\
\text { Car- } \\
\text { bonate } \\
\text { Min- } \\
\text { erals }\end{array}$} & \multirow{2}{*}{$\begin{array}{l}\text { Othe } \\
\text { Min- } \\
\text { erals }\end{array}$} \\
\hline & $\begin{array}{l}\text { Montmori- } \\
\text { llonite }\end{array}$ & Illite & $\begin{array}{r}\text { Kao- } \\
\text { linite }\end{array}$ & $\begin{array}{c}\text { Chlor- } \\
\text { ite }\end{array}$ & $\begin{array}{l}\text { Mixed } \\
\text { Layer }\end{array}$ & & & & & & & \\
\hline \multicolumn{13}{|l|}{ Site 354} \\
\hline $\begin{array}{l}1-1,75 \\
1-1,140 \\
2, C C \\
3-1,110 \\
4-1,60-62 \\
4-2,60-62 \\
4-4,75 \\
4-6,10 \\
4-6,102 \\
5-2,91-93 \\
6-3,84 \\
6-3.94 \\
6-3,138 \\
7-3,43 \\
8-2,5 \\
9-1,117 \\
10-2,126 \\
11-2,79 \\
12-5,40 \\
12-5,91 \\
13-6,124 \\
14-4,35-40 \\
15-2,35 \\
15-3,138 \\
16-2,47 \\
16-6,124 \\
17-1,127 \\
18-1,130 \\
18-4,127\end{array}$ & $\begin{array}{r}12.2 \\
10.1 \\
9.9 \\
8.9 \\
8.5 \\
4.7 \\
8.6 \\
8.4 \\
6.8 \\
7.0 \\
8.9 \\
5.6 \\
13.1 \\
8.6 \\
18.7 \\
5.5 \\
8.7 \\
9.7 \\
9.5 \\
6.8 \\
8.6 \\
6.5 \\
8.6 \\
16.0 \\
11.2 \\
21.0 \\
4.3 \\
4.8 \\
4.5\end{array}$ & $\begin{array}{l}22.2 \\
19.0 \\
19.7 \\
16.7 \\
13.8 \\
14.8 \\
16.2 \\
21.3 \\
11.4 \\
14.0 \\
15.2 \\
2.8 \\
4.2 \\
\operatorname{tr} \\
\operatorname{tr} \\
4.2 \\
5.2 \\
6.1 \\
0.0 \\
3.4 \\
4.8 \\
3.7 \\
\operatorname{tr} \\
4.8 \\
4.8 \\
\operatorname{tr} \\
4.8 \\
5.4 \\
5.9\end{array}$ & $\begin{array}{r}9.1 \\
7.6 \\
9.7 \\
5.6 \\
5.3 \\
6.8 \\
8.1 \\
12.6 \\
6.3 \\
8.8 \\
10.2 \\
7.0 \\
25.4 \\
6.5 \\
15.5 \\
5.4 \\
6.6 \\
12.1 \\
\operatorname{tr} \\
3.5 \\
3.2 \\
4.9 \\
0.0 \\
3.6 \\
0.0 \\
0.0 \\
18.4 \\
24.0 \\
28.7\end{array}$ & $\begin{array}{c}7.8 \\
6.3 \\
7.4 \\
4.4 \\
4.2 \\
4.5 \\
6.5 \\
11.3 \\
5.1 \\
5.3 \\
5.1 \\
\operatorname{tr} \\
\operatorname{tr} \\
0.0 \\
7.8 \\
0.0 \\
3.9 \\
\operatorname{tr} \\
0.0 \\
0.0 \\
0.0 \\
3.5 \\
0.0 \\
\operatorname{tr} \\
0.0 \\
0.0 \\
\operatorname{tr} \\
0.0 \\
0.0\end{array}$ & $\begin{array}{l}0.0 \\
0.0 \\
0.0 \\
0.0 \\
0.0 \\
0.0 \\
0.0 \\
0.0 \\
0.0 \\
0.0 \\
0.0 \\
0.0 \\
0.0 \\
0.0 \\
0.0 \\
0.0 \\
0.0 \\
0.0 \\
0.0 \\
0.0 \\
0.0 \\
0.0 \\
0.0 \\
0.0 \\
0.0 \\
0.0 \\
0.0 \\
0.0 \\
0.0\end{array}$ & $\begin{array}{r}15.2 \\
12.7 \\
13.1 \\
9.3 \\
7.1 \\
4.9 \\
12.4 \\
10.0 \\
4.6 \\
9.9 \\
10.1 \\
1.9 \\
5.6 \\
2.7 \\
6.7 \\
2.8 \\
4.1 \\
12.2 \\
1.8 \\
3.9 \\
2.7 \\
2.0 \\
9.4 \\
17.2 \\
18.5 \\
11.8 \\
16.0 \\
15.8 \\
20.6\end{array}$ & $\begin{array}{l}2.6 \\
\mathrm{tr} \\
\mathrm{tr} \\
1.1 \\
1.1 \\
0.0 \\
\mathrm{tr} \\
1.3 \\
0.0 \\
0.0 \\
0.0 \\
0.0 \\
0.0 \\
0.0 \\
3.1 \\
0.0 \\
0.0 \\
0.0 \\
0.0 \\
0.0 \\
0.0 \\
0.0 \\
0.0 \\
0.0 \\
0.0 \\
0.0 \\
0.0 \\
1.8 \\
2.5\end{array}$ & $\begin{array}{c}3.9 \\
3.8 \\
2.5 \\
2.2 \\
2.1 \\
1.3 \\
1.6 \\
2.5 \\
\mathrm{tr} \\
\mathrm{tr} \\
\mathrm{tr} \\
0.0 \\
0.0 \\
0.0 \\
1.6 \\
0.0 \\
0.0 \\
0.0 \\
0.0 \\
0.0 \\
0.0 \\
0.0 \\
3.9 \\
\mathrm{tr} \\
0.0 \\
0.0 \\
0.0 \\
0.0 \\
0.0\end{array}$ & $\begin{array}{l}0.0 \\
0.0 \\
0.0 \\
0.0 \\
0.0 \\
0.0 \\
0.0 \\
0.0 \\
0.0 \\
0.0 \\
0.0 \\
0.0 \\
0.0 \\
0.0 \\
0.0 \\
0.0 \\
0.0 \\
0.0 \\
0.0 \\
0.0 \\
0.0 \\
5.0 \\
0.0 \\
0.0 \\
0.0 \\
0.0 \\
0.0 \\
0.0 \\
0.0\end{array}$ & $\begin{array}{l}0.0 \\
0.0 \\
0.0 \\
0.0 \\
0.0 \\
0.0 \\
0.0 \\
0.0 \\
0.0 \\
0.0 \\
0.0 \\
0.0 \\
0.0 \\
0.0 \\
0.0 \\
0.0 \\
0.0 \\
4.9 \\
0.0 \\
0.0 \\
0.0 \\
2.3 \\
0.0 \\
0.0 \\
0.0 \\
0.0 \\
0.0 \\
0.0 \\
0.0\end{array}$ & $\begin{array}{l}27.0 \\
40.5 \\
37.7 \\
51.8 \\
57.9 \\
63.0 \\
46.6 \\
32.6 \\
65.8 \\
55.0 \\
50.5 \\
82.7 \\
51.7 \\
82.2 \\
46.6 \\
82.1 \\
72.5 \\
55.0 \\
88.7 \\
82.4 \\
80.7 \\
72.1 \\
78.1 \\
58.4 \\
65.5 \\
67.2 \\
56.5 \\
48.2 \\
37.8\end{array}$ & \\
\hline \multicolumn{13}{|l|}{ Site 355} \\
\hline $\begin{array}{l}1-2,72-74 \\
2-3,50-52 \\
2-5,130-132 \\
3-2,90-92 \\
3-5,60-62 \\
4-3,110-112 \\
5-1,38-40 \\
5-4,100-102 \\
6-2,66-68 \\
7-2,90-92 \\
7-3,100-102 \\
8-2,120-121 \\
9-2,58-60 \\
11-2,86-88 \\
12-5,86-88 \\
13-3,75-77 \\
15-1,86 \\
15-1,101 \\
17-3,143-145 \\
17-4,20-22 \\
17-6,65-67 \\
18-1,120-122 \\
18-3,41-43 \\
19-2,131-133 \\
20-2,148-150\end{array}$ & $\begin{array}{r}25.8 \\
34.8 \\
33.5 \\
18.9 \\
51.6 \\
38.1 \\
26.5 \\
28.8 \\
49.4 \\
35.8 \\
31.5 \\
13.8 \\
14.8 \\
17.5 \\
28.6 \\
35.1 \\
19.6 \\
34.1 \\
4.1 \\
3.8 \\
6.4 \\
5.3 \\
7.2 \\
5.1 \\
3.9\end{array}$ & $\begin{array}{r}24.2 \\
18.6 \\
28.7 \\
9.9 \\
23.3 \\
19.0 \\
8.6 \\
12.3 \\
7.4 \\
8.9 \\
7.3 \\
4.2 \\
9.7 \\
6.6 \\
7.1 \\
13.2 \\
50.6 \\
30.7 \\
6.2 \\
7.2 \\
\operatorname{tr} \\
4.0 \\
8.1 \\
12.7 \\
4.4\end{array}$ & $\begin{array}{c}12.9 \\
12.9 \\
7.2 \\
\mathrm{tr} \\
\mathrm{tr} \\
11.1 \\
6.6 \\
4.1 \\
0.0 \\
6.1 \\
6.7 \\
\mathrm{tr} \\
4.6 \\
0.0 \\
6.1 \\
9.2 \\
10.0 \\
9.5 \\
0.0 \\
0.0 \\
0.0 \\
0.0 \\
0.0 \\
3.4 \\
0.0\end{array}$ & $\begin{array}{c}6.5 \\
10.1 \\
3.6 \\
\operatorname{tr} \\
\mathrm{tr} \\
10.1 \\
7.9 \\
2.1 \\
0.0 \\
5.6 \\
10.1 \\
\mathrm{tr} \\
5.6 \\
0.0 \\
7.7 \\
7.9 \\
4.4 \\
10.9 \\
0.0 \\
0.0 \\
0.0 \\
0.0 \\
0.0 \\
\operatorname{tr} \\
0.0\end{array}$ & $\begin{array}{l}0.0 \\
0.0 \\
0.0 \\
0.0 \\
0.0 \\
0.0 \\
0.0 \\
0.0 \\
0.0 \\
0.0 \\
0.0 \\
0.0 \\
0.0 \\
0.0 \\
0.0 \\
0.0 \\
0.0 \\
0.0 \\
0.0 \\
0.0 \\
0.0 \\
0.0 \\
0.0 \\
0.0 \\
0.0\end{array}$ & $\begin{array}{r}17.7 \\
16.1 \\
14.4 \\
4.2 \\
11.6 \\
9.0 \\
10.6 \\
11.6 \\
9.9 \\
10.1 \\
8.9 \\
4.8 \\
7.4 \\
7.0 \\
8.2 \\
6.6 \\
6.6 \\
11.4 \\
2.6 \\
2.9 \\
1.6 \\
1.8 \\
4.5 \\
4.7 \\
2.0\end{array}$ & $\begin{array}{l}4.8 \\
\operatorname{tr} \\
\operatorname{tr} \\
0.0 \\
0.0 \\
0.0 \\
0.0 \\
4.1 \\
0.0 \\
3.4 \\
3.4 \\
2.1 \\
2.8 \\
0.0 \\
0.0 \\
0.0 \\
5.5 \\
3.4 \\
0.0 \\
0.0 \\
0.0 \\
0.0 \\
1.3 \\
1.3 \\
0.0\end{array}$ & $\begin{array}{c}8.1 \\
7.5 \\
7.1 \\
2.8 \\
7.7 \\
6.3 \\
6.0 \\
6.2 \\
0.0 \\
8.3 \\
3.9 \\
1.7 \\
4.2 \\
2.5 \\
3.0 \\
2.6 \\
3.3 \\
\text { tr } \\
0.0 \\
0.0 \\
0.0 \\
0.0 \\
1.8 \\
\text { tr } \\
0.0\end{array}$ & $\begin{array}{r}0.0 \\
0.0 \\
0.0 \\
0.0 \\
0.0 \\
0.0 \\
0.0 \\
0.0 \\
0.0 \\
0.0 \\
0.0 \\
6.9 \\
23.1 \\
15.3 \\
25.5 \\
7.0 \\
0.0 \\
0.0 \\
0.0 \\
0.0 \\
0.0 \\
0.0 \\
0.0 \\
0.0 \\
0.0\end{array}$ & $\begin{array}{r}0.0 \\
0.0 \\
5.5 \\
0.0 \\
5.8 \\
6.4 \\
33.8 \\
30.8 \\
33.3 \\
21.8 \\
28.4 \\
66.5 \\
27.8 \\
51.1 \\
13.8 \\
18.4 \\
0.0 \\
0.0 \\
0.0 \\
0.0 \\
0.0 \\
0.0 \\
0.0 \\
0.0 \\
0.0\end{array}$ & $\begin{array}{c}0.0 \\
\text { tr } \\
0.0 \\
64.2 \\
0.0 \\
0.0 \\
0.0 \\
\operatorname{tr} \\
0.0 \\
0.0 \\
0.0 \\
0.0 \\
0.0 \\
0.0 \\
0.0 \\
0.0 \\
0.0 \\
0.0 \\
87.1 \\
86.1 \\
92.0 \\
88.9 \\
77.1 \\
72.8 \\
89.7\end{array}$ & \\
\hline \multicolumn{13}{|l|}{ Site 357} \\
\hline $\begin{array}{l}1-3,100-103 \\
3-2,90-92 \\
5-3,100-102\end{array}$ & $\begin{array}{l}3.3 \\
2.6 \\
2.2\end{array}$ & $\begin{array}{l}0.0 \\
\text { tr. } \\
2.8\end{array}$ & $\begin{array}{l}0.0 \\
0.0 \\
0.0\end{array}$ & $\begin{array}{l}0.0 \\
0.0 \\
0.0\end{array}$ & $\begin{array}{l}0.0 \\
0.0 \\
0.0\end{array}$ & $\begin{array}{l}1.8 \\
\text { tr. } \\
3.3\end{array}$ & $\begin{array}{l}0.0 \\
0.0 \\
0.0\end{array}$ & $\begin{array}{l}0.0 \\
0.0 \\
1.6\end{array}$ & $\begin{array}{l}0.0 \\
0.0 \\
0.0\end{array}$ & $\begin{array}{l}0.0 \\
0.0 \\
0.0\end{array}$ & $\begin{array}{l}95.2 \\
97.4 \\
90.5\end{array}$ & $\begin{array}{l}0.0 \\
0.0 \\
0.0\end{array}$ \\
\hline
\end{tabular}


TABLE 5 - Continued

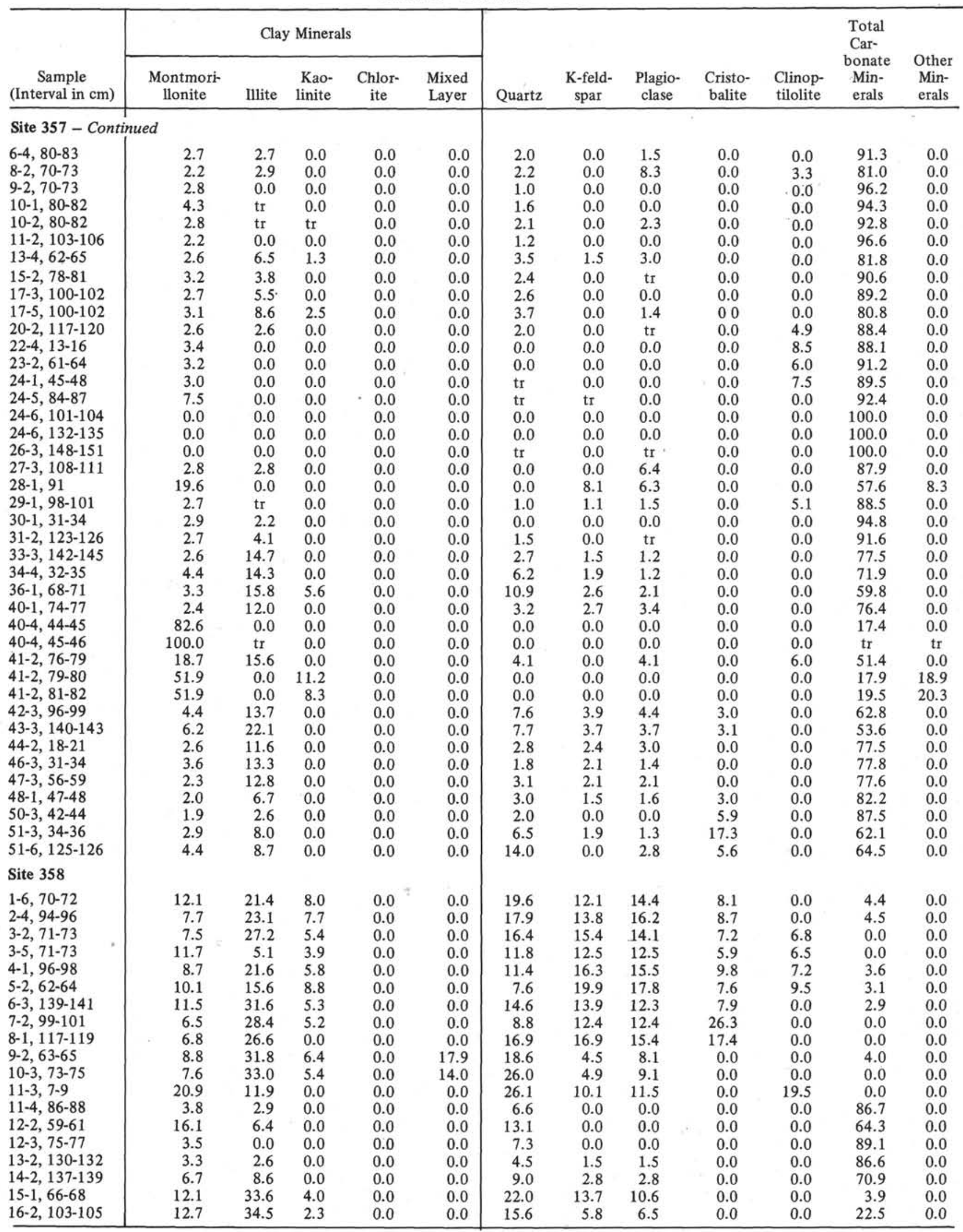




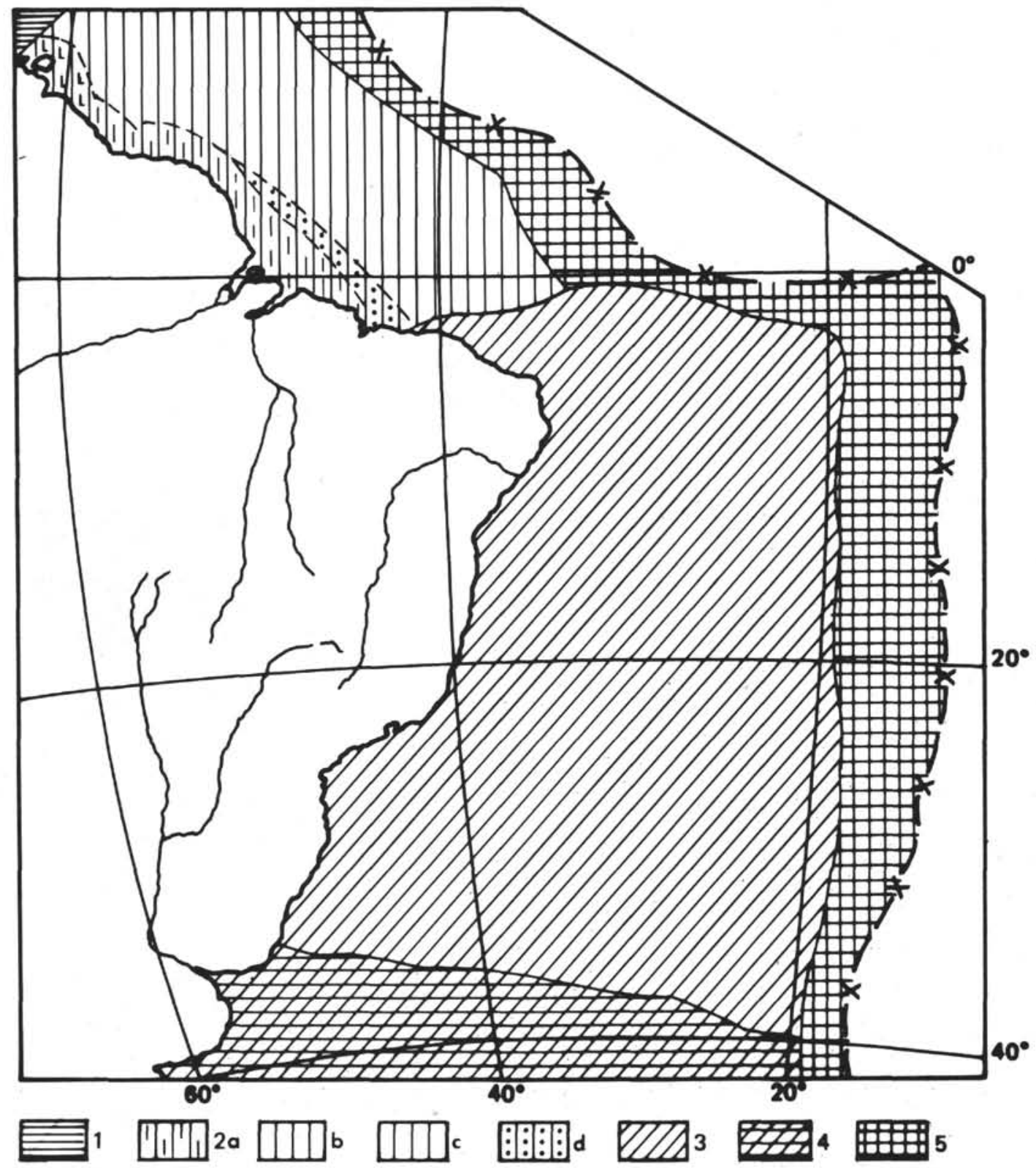

Figure 2. Mineralogic provinces of large aleurite fraction of upper-layer sediments of the Atlantic Ocean (by Emelyanov and Kharin, 1974; A.V. Soldatov et al., unpublished data). Legend: 1-Lesser Antilles volcanogenic; 2-Guiana (pyroxene-zircon-epidote-amphibole) with subprovinces ( $a$-Amazonian, b-Orinocina, c-Guiana deep-water, $d$-Tocantincan relict); 3-Brazilian (ilmenite-pyroxene-zircon-epidote); 4-Argentine (ilmenite-pyrozene-amphibole); 5-Mid-Atlantic Ridge (olivine-pyroxene-amphibole-serpentine).

American basins in respect with solid evacuations of the Amazon and Orinoco rivers): Litologiya i polezn. iskop., v. 2 , p. $22-35$.

Etchichury, M.C. and Remiro, J.R., 1960. Muestras de fondo de la platforma continental: Ciencias Geologicas, v. VI, Buenos-Aires, p. 197-263.

Etchichury, M.C. and Remiro, J.R., 1963. La corriente de Malvinas y los sedimentos Pampeano-Patagónicos: Ciencias Geológicas, v. I, Buenos Aires, p. 1-11.

Gibbs, R.J., 1967. The geochemistry of Amazon river system: part 1. The factors that control the salinity and the composition and concentration of the suspended solids: Geol. Soc. Am. Bull., v. 78, p. 1203-1232.

Gorbunova, Z.N., 1969. Rentgen-difraktometricheskiy metod opredeleniya karbonatov i drugikh mineralov osadka. (X-ray diffractometric analysis of determining carbonates, quartz and other minerals of sediments): Litologiya i polezn. iskop., v. 2, p. 125-130.

Groot, J.J., Groot, G.R., Ewing, M., Burckle, L., and Conolly, J.R., 1967. Spores, pollen, diatoms and province of the Argentine Basin sediments: Progress in Oceanography, v. 4, Pergamon Press, p. 179-217.

Krinsley, D., Biscaye, P.E., and Turekian, K.K., 1973. Argentine basin sediment sources as indicated by quartz surface textures: J. Sediment. Petrol., v. 43, p. 251-257.

Milliman, J.D., Summerhayes, C.P., and Barretto, H.T., 1975. Oceanography and suspended matter off the Amazon river February-March: J. Sediment. Petrol., v. 45 , p. $189-206$. 


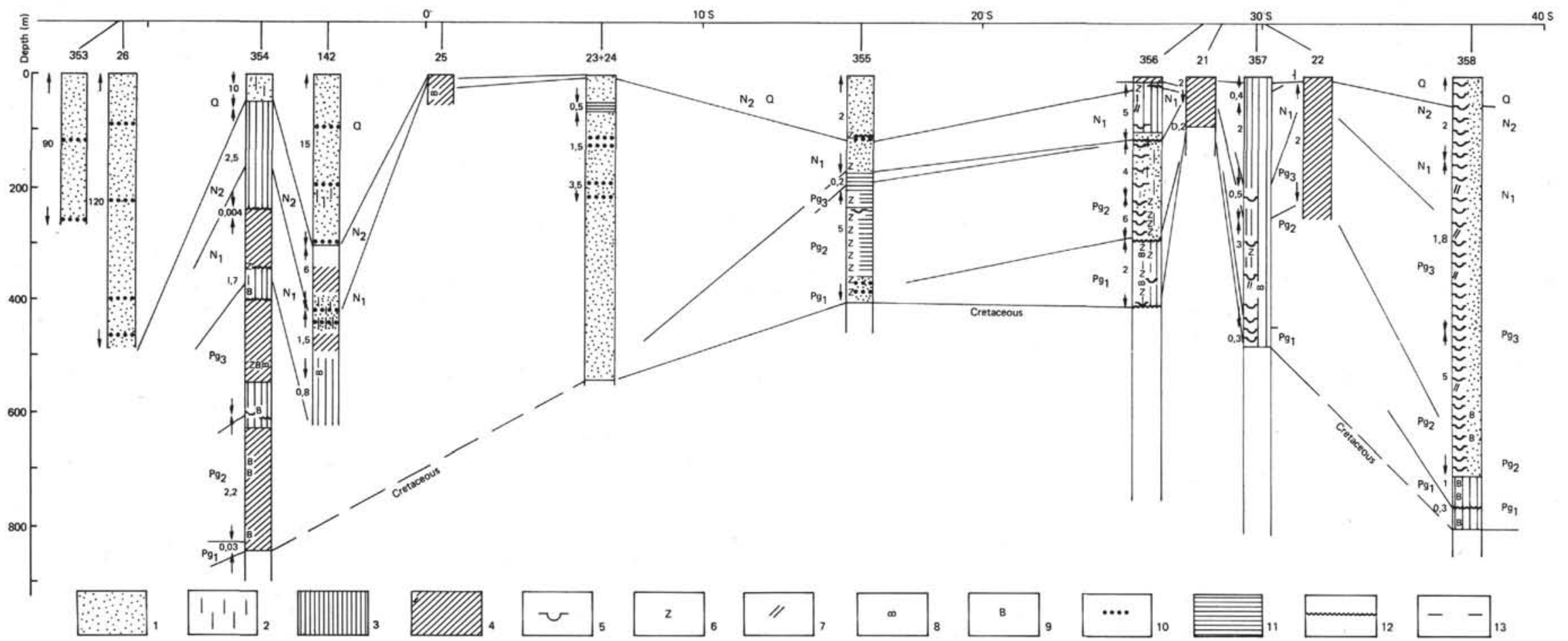

Figure 3. Cenozoic deposits at sites of the western South Atlantic. Legend: 1-4 indicate $\mathrm{CaCO}_{3}$ content of sediments (1-less than 10\%, 2-10-30\%, 3-30-60\%, 4-more than $60 \% \mathrm{CaCO}_{3}$ ); 5-siliceous material (10-50\%); 6-zeolites (over 10\%); 7-volcanogenic material (over 10\%); 8-brecciated layers, slumping deposits; 9-admixture of barite; 10 -turbidites; 11-red clays; 12-hiatuses; 13 -rates of sediment accumulation in $\mathrm{cm} / 1000$ years. 
Oliveira, A.I., 1956. Brazil. In Jenks, W.F. (Ed.), Handbook of South American Geology: Geol. Soc. Am. Mem., v. 65, p. 2-62.

Petelin, V.P., 1961. Novyiy metod vodnogo mekhanicheskogo analiza morskikh osadkov (New method of water mechanical analysis of marine sediments): Okeanologiya, v. 1 , p. $143-148$.

Petelin, V.P., 1967. Granulometricheskiy analiz morskikh donnykh osadkov (Granulometric analysis of marine bottom sediments), Izd-vo "Nauka", Moscow, p. 1-75.

Prokoptsev, N.G., 1964. K metodike mekhanicheskogo analiza pelitovykh fraktsiy morskikh osadkov-suspenzionnye vesy. (On method of mechanical analysis of pelitic fractions of marine sediments-suspensional weight): Okeanologiya, v. 4, p. 699-707.

Rex, R.W. and Murray, B., 1970. X-ray mineralogy studies, Leg 4. In Bader, R.G. et al., Initial Reports of the Deep
Sea Drilling Project, Volume 4: Washington (U.S. Government Printing Office), p. 325-370.

Shurko, I.I., 1968. Mineralogicheskiye zony i provintsii $v$ osadkakh Atlanticheskogo okeana (Mineralogic zones and provinces in sediments of the Atlantic Ocean): Litologiya i polezn. iskop., v. 4, p. 112-117.

Shurko, I.I., 1971. Osobennosti pozdnechetvertichnogo osadkoobrazovaniya v Argentinskoy kotlovine. (The features of late Quaternary sedimentation in the Argentine Basin). Doklady AN SSSR, v. 198, p. 696-698.

Von Rad, U. and Rösch, H., 1972. Mineralogy and origin of clay minerals, silica and authigenic silicates in Leg 14 sediments. In Hayes, D.E., Pimm, A.C., et al., Initial Reports of the Deep Sea Drilling Project, Volume 14: Washington (U.S. Government Printing Office), p. $727-$ 752. 